\title{
Developments
}

\section{After the Dust Has Settled: How to Construct the New Accession Agreement After Opinion 2/13 of the CJEU}

\author{
By Przemyslaw Tacik*
}

\begin{abstract}
Since December 18, 2014, when the Court of Justice of the European Union (CJEU) issued its notorious Opinion $2 / 13$, the conclusions of the Court have been a subject of numerous analyzes and debates-often sharp in their criticism. Now that the content of the Opinion seems fairly elucidated, the scholarly attention should turn towards searching for practical solutions to the CJEU's demands. This Article aims to provide a list of possible solutions to each requirement of the Opinion and assessing their pros and cons. Instead of concentrating on the obstacles posed by the Court, it is incumbent to address the problems with innovative legal thinking and save the project of the EU acceding to the European Convention on Human Rights (ECHR).
\end{abstract}

\footnotetext{
* Przemyslaw Tacik holds PhDs in philosophy and in international law. He is an assistant professor at the Institute of European Studies, Jagiellonian University in Krakow. Dr. Tacik would like to thank the staff and guests of the MaxPlanck-Institut für ausländisches öffentliches Recht und Völkerrecht-particularly Professor Jochen Abr. Frowein and Mr. Christoph Krenn-for helpful discussions while working on this article. He can be reached via e-mail at przemyslaw.tacik@gmail.com.
} 


\section{A. Introduction}

It has been over two years and a half since the Court of Justice of the European Union (CJEU) issued its notorious Opinion $2 / 13^{1}$ on the incompatibility with the EU Treaties of the Draft Accession Agreement ${ }^{2}$ (DAA) through which the EU was meant to accede to the ECHR. ${ }^{3}$ One can hardly imagine a more genuine surprise for a vast majority of scholars, as well as for some EU institutions which staunchly supported the DAA. ${ }^{4}$ Outpourings of disappointment, if not despair, dominated the direct aftermath of the opinion ${ }^{5}$ which was even dubbed a "Christmas bombshell from the Court." ${ }^{\prime}$ After the initial heated reactions, however, more poised voices were heard and the debate took a rational turn with pros and cons of the Court's stance on particular accession issues being studied in more detail.

${ }^{1}$ Case 2/13, Adhésion de l'Union à la CEDH (Dec. 18, 2014), http://curia.europa.eu/.
${ }^{2}$ DRAFT REVISED AGREEMENT ON THE ACCESSION OF THE EUROPEAN UNION TO THE CONVENTION FOR THE PROTECTION OF HUMAN
$\begin{array}{llccc}\text { RIGHTS AND } & \text { FUNDAMENTAL } & \text { FREEDOMS } & \text { (Jun. }\end{array}$ $\begin{array}{llcc}\text { RIGHTS AND } & \text { FUNDAMENTAL } & \text { FREEDOMS } & \text { (Jun. } \\ \text { http://romatrepress.uniroma3.it/ojs/index.php/Convenzioni/article/download/204/203. }\end{array}$

${ }^{3}$ Convention on the Protection of Human Rights and Fundamental Freedoms, E.T.S. No. 005 [hereinafter ECHR].

${ }^{4}$ See Louise Halleskov Storgaard, EU Law Autonomy versus European Fundamental Rights Protection-On Opinion 2/13 on EU Accession to the ECHR, 15 HUM. RTS. L. REV. 491 (2015); CMLR Editorial Comments, The EU's Accession to the ECHR - $a$ "NO" from the ECJ!, 52 CMLR 1 (2015).

${ }^{5}$ See Tobias Lock, Oops! We did it again-das Gutachten des EuGH zum EMRK-Beitritt der EU, VERFASSUNGSBLOG (Apr. 13, 2015), http://www.jurablogs.com/go/oops-we-did-it-again-das-gutachten-des-eugh-zum-emrk-beitritt-der-eu; Sionaidh Douglas-Scott, Opinion 2/13 on EU accession to the ECHR: a Christmas bombshell from the European Court of Justice, VERFASSUnGSBLOG (Apr. 13, 2015), http://www.verfassungsblog.de/en/opinion-213-eu-accession-echrchristmas-bombshell-european-court-justice/\#VgKGjH3UXm4; Jean-Paul Jacqué, Non à l'adhésion à la Convention européenne des droits de l'homme?, DR. U. E. (Apr. 13, 2015), http://www.droit-union-europeenne.be/412337458; Christian Tomuschat, Der Streit um die Auslegungshoheit: Die Autonomie der EU als Heiliger Gral. Das EuGHGutachten gegen den Beitritt der EU zur EMRK, 42 EUGRZ 133 (2015); Marten Breuer, «Wasch mir den Pelz, aber mach mich nicht nass!». Das zweite Gutachten des EuGH zum EMRK-Beitritt der Europäischen Union, EUR 330 (2015); Jean-Paul Jacqué, Pride and/or Prejudice? Les lectures possibles de l'avis 2/13 de la Cour de Justice, 51 CAH. DR. EUR. 19 (2015); Francesco Cherubini, The Relationship Between the Court of Justice of the European Union and the European Court of Human Rights in the View of the Accession, 16 GERMAN L.J. 1385 (2015); Daniel Halberstam, "It's the Autonomy, Stupid!" A Modest Defense of Opinion 2/13 on EU Accession to the ECHR, and the Way Forward, 16 GERMAN L. J. 105 (2015); Stian $\emptyset$ by Johansen, The Reinterpretation of TFEU Article 344 in Opinion 2/13 and Its Potential Consequences, 16 German L.J. 169 (2015); Adam Łazowski, Ramses A. Wessel, When Caveats Turn into Locks: Opinion 2/13 on Accession of the European Union to the ECHR, 16 GERMAN L.J. 179 (2015); Christoph Krenn, Autonomy and Effectiveness as Common Concerns: A Path to ECHR Accession After Opinion 2/13, 16 GERMAN L.J. 147 (2015); CMLR Editorial Comments, supra note 4, at 1; Daniel Thym, Das EMRK-Gutachten des EuGH, 5 EUZW 180 (2015); Édouard Dubout, Une question de confiance: nature juridique de l'Union européenne et adhésion à la Convention européenne des droits de l'homme, 51 CAH. DR. EUR. 75 (2015).

${ }^{6}$ See Douglas-Scott, supra note 5. 
Throughout 2015, numerous valuable contributions have been published which aimed to clarify the sometimes-murky line of argumentation of the CJEU. ${ }^{7}$ Nevertheless, it is slightly astonishing how easily most of these analyses tended to take sides in criticism of the Opinion instead of viewing it as an obstacle to be overcome; either they expressed strong disapproval of the Court's approach, or attempted to defend it, albeit usually in a moderate tone. After over two years and a half we are richer in experience, and it seems that it is no longer of any avail to resume such a debate. The Opinion has been clarified as much as possible, so it is reasonable to now take a step further and join the current efforts of the European Commission in outlining exits from the deadlock created by this ruling. Meeting the current Court's demands, however arduous a task it appears, unfortunately cannot guarantee a happy ending. There are some areas of the DAA which in the future might pose a challenge to its compatibility with the Treaties, ${ }^{8}$ although the Court did not note them in Opinion 2/13. Therefore, it seems crucial to use the time that nolens volens the CJEU provided to vet the agreement and find its other potential weaknesses, which might make the story repeat itself.

This Article focuses on one main objective: It aims at listing possible solutions to the Court's demands with particular attention to their feasibility. Drawing upon the contributions which were published since the Opinion of the CJEU had been issued, it attempts to provide a succinct overview of the most important proposals which appeared in the literature of the subject. Based on these findings, it argues for pragmatic ways of confronting the Court's demands. Now that the debate over the Opinion's pros and cons is over, it is time for careful analysis of what can be done.

Given that Opinion 2/13 was issued on December 18, 2014, a long time passed before any official EU institutional action-most notably the Commission, which was and will be in charge of accession negotiations. Before 2016, the Commission was willing to adopt only two official declarations, although they had hardly determined the precise direction. The first declaration came from Commissioner Timmermans, who during a session of the European Parliament on February 12, 2015, stated that the accession still constitutes a priority for the Commission, but because of its complexity, the task requires a longer time for reflection. ${ }^{9}$ The second declaration was issued through the 2014 Report on the

${ }^{7} \mathrm{Cf}$. citations at supra note 4; citations at supra 6; Steve Peers, The EU's Accession to the ECHR: The Dream Becomes a Nightmare, 16 GeRman L.J. 213 (2015); Piet Eeckhout, Opinion 2/13 on EU Accession to the ECHR and Judicial Dialogue: Autonomy or Autarky?, 38 FORDHAM INT'L L.J. 955 (2015); Tobias Lock, The Future of the European Union's Accession to the European Convention on Human Rights after Opinion 2/13: Is it still possible and is it still desirable?, 11 EUR. CONST. L. REV. 239 (2015); Sarah Lambrecht, The Swing is in the Tail: CJEU Opinion 2/13 objects to draft agreement on accession of the EU to the European Convention on Human Rights, 2 EUR. HUM. RTS L. REV. 185 (2015).

${ }^{8}$ By "the Treaties" I will understand the Treaty on the European Union (TEU) and the Treaty on the Functioning of the European Union (TFEU), as modified by the Treaty of Lisbon.

${ }^{9}$ See Commission Statement: EU Framework for democracy, rule of law and fundamental rights, Speech of First Vice-President Frans Timmermans to the European Parliament (Feb. 12, 2015), http://europa.eu/rapid/pressrelease_SPEECH-15-4402_en.htm. 
Application of the Charter of Fundamental Rights ${ }^{10}$ (CFR) and was even more laconic. The Report stated that the Commission would make efforts to prepare new initiatives for the accession. Apart from these two superficially reassuring statements, there had been no official confirmation that the preparations within the Commission are on the right track.

This silence shouldn't have been taken for an ominous tone. The Commission revealed in its 2015 Report on the Application of the CFR that after the reflection period, it started consulting "with the special committee designated by the Council on concrete solutions for the different issues raised in the opinion of the Court of Justice." ${ }^{11}$ Relying on this statement, it appears the mood toward Opinion 2/13 has turned from a "cooling off" phase to a "solutions" phase.

The task of drafting a new Accession Agreement (AA) is arduous, but not-as I will argue-impossible. Given the covert nature of the 2010-11 first round of negotiations and of the subsequent inner EU discussion of the draft, ${ }^{12}$ it is expected that the Commission will handle this issue-which has become even more fragile-with reticence. To avoid a repetition of the " $2 / 13$ scenario," it seems reasonable not only to take sufficient time to analyze the possible content of the future $\mathrm{AA}$, but also to undertake unofficial consultations with other EU institutions. Since the CJEU already took an unprecedented step in issuing its 2010 Discussion document ${ }^{13}$ through which it intervened actively in the negotiation process, the Commission should not regard the Court as a purely neutral observer. ${ }^{14}$ Given the complexity of the task, unofficial consultations with the CJEU might pave the way for drafting an agreement which would be more likely to meet the requirements formulated at the Kirchberg Hill.

It should also be remembered that Article 6(2) of the Treaty on the European Union (TEU) ${ }^{15}$ requires the EU to accede to the ECHR, according to most interpretations. Even though the Court in Opinion 2/13 did not provide any insightful remarks on the precise content and

\footnotetext{
${ }^{10}$ See The European Commission, 2014 Report on the application of the EU Charter of Fundamental Rights 15 (2014), http://ec.europa.eu/justice/fundamental-rights/charter/application/index_en.htm.

${ }^{11}$ See The European Commission, 2015 Report on the application of the EU Charter of Fundamental Rights 13, 23 (2015), http://ec.europa.eu/justice/fundamental-rights/charter/application/index_en.htm.

${ }^{12}$ See Sionaidh Douglas-Scott, The European Union and Human Rights after the Treaty of Lisbon, 11 HUM. RTS. L. REV. 645, 661-62 (2011).

${ }^{13}$ See The Court of Justice of the European Union, Discussion Document of the Court of Justice of the European Union on Certain Aspects of the Accession of the European Union to the European Convention for the Protection of Human Rights and Fundamental Freedoms, (May 5, 2010), http://curia.europa.eu/jcms/upload/docs/application/pdf/2010-05/convention_en.pdf.

${ }^{14} \mathrm{Cf}$. CMLR Editorial Comments, supra note 4, at 13.

${ }^{15}$ Treaty on the European Union (consolidated version), Feb. 7, 1992, 2016 O.J. (C 202) 13 [hereinafter TEU].
} 
scope of this obligation or might have even disregarded it in favor of arguments referring to EU autonomy, it cannot be inferred that it gave a carte blanche for a never-ending drafting process. Preparatory works within the Commission-as much as they are necessary-cannot border on procrastination, and neither can the future actions of other EU institutions and the Member States. ${ }^{16}$ Not only was the quick accession process a priority ever since the socalled Stockholm program adopted in 2009, ${ }^{17}$ but, according to some commentators, ${ }^{18}$ it is also stipulated by Article 6 (2) of the TEU. Naturally, it would be hardly imaginable to see infringement proceedings being instigated against the Commission for an unjustified delay in resuming the accession process. ${ }^{19}$ The matter seems too complex and politically entangled to treat it just as mere realization of Treaty obligations. Even if the demand for speedy negotiations was not linked with the aforementioned obligation to accede, excessive prolongation of preparatory works should be avoided at least to protect the EU's credibility and reliability.

This stage of the accession process, however, will be difficult not only because of the high threshold of the Court's demands, but also because of a more complicated international context. Now it is much less conducive to a successful accession than in 2010 when the first round of negotiations started and even in 2013, when the accession agreement was finally drafted. Tensions in EU relations with Russia after the Crimea crisis are likely to hinder the process given that Russia subtly played a political card in previous rounds of negotiations as well as in the ratification of the Protocol No. 14 to the ECHR. ${ }^{20}$ As the Russian Federation is one of the parties to the Convention, its acceptance of the Accession Agreement is a condition of the entry into force of the accession agreement. This effective dependence appears as a challenge to the accession process. Obtaining Russian consent to some of the provisions of the 2013 Draft was already a real achievement of EU diplomacy, so more advanced changes necessitated by Opinion $2 / 13$ will hardly be met with understanding and acceptance in times of cold relations between the EU and the Russian Federation.

Another factor hindering the international context of the next stage of the accession process is the pronounced decline of solidarity within the EU, recently aggravated by the Brexit.

\footnotetext{
${ }^{16} \mathrm{Cf}$. Peers, supra note 7, at 219.

${ }^{17}$ Vassilios Skouris, Aspekte des Beitritts der Europäischen Union zur Europäischen Konvention für Menschenrechte, in EUROPÄIISCHES RECHT ZWISCHEN BEWÄHRUNG UND WANDEL. FESTSCHRIFT FÜR DIETER H. SCHEUING 212 (Peter Müller-Graff et al. eds., 2011).

${ }^{18} \mathrm{Cf}$. Andrea Huber, Der Beitritt der EuropäIsChen Union zUR EURopäisChen MensChenReChtSKonvention. ARt. 6 Abs. 2 S. 1 EUV 33-34 (2008).

${ }^{19} \mathrm{Cf}$. Peers, supra note 7, at 219.

20 José Rafael Ais Marìn, La adhesión de la Unión Europea al Convenio de Roma. El cumplimiento de las obligaciones derivadas del Convenio Europeo de Derechos Humanos en el ordenamiento jurídico de la UE, 44 REVISTA DE DERECHO COMUNITARIO EUROPEO 236 (2013).
} 
Contrary to the spirit of the Treaties, many EU countries are becoming more domestically focused with the refugee crisis acting as a powerful trigger of anti-integration sentiments. Although the EU accession to the ECHR was often viewed as one of the long-postponed grands projets of European integration, it might be too removed from EU citizens' direct personal sphere to rekindle the pro-European spirit. As a result, EU Member States might now be less interested in developing a new draft Accession Agreement. The current situation naturally demands that more attention be paid to maintaining an effective political and economic union than to the convoluted and formalistic process of the EU accession to the ECHR.

Nevertheless, accession's small scale in comparison with other projects of strengthening the integration and pro-citizen character might work in its favor. Subjecting the EU to the external judicial control of the European Court of Human Rights (ECtHR) might be particularly relevant in times of the refugee crisis when a significant number of regulations concerning asylum seekers stems from EU law. Whichever approach the Member States take, it is crucial that the accession agreement and the process of its ratification should not be used as a vehicle for political bargains concerning other matters. It would significantly diminish the symbolic value of the accession, thus undermining the position of the EU as a human rights defender.

Although accession's political and international context do not seem particularly favorable, the EU is still obliged to undertake steps to realize it. Setting aside all criticisms of the CJEU's stance, it is time to reflect on the possible ways of effectively meeting its demands.

\section{B. The Ten Points of the CJEU and Practical Solutions}

The CJEU declared ten points in which the DAA is incompatible with EU Treaties, although five of them might be regrouped into two narrower categories concerning the corespondent mechanism and the prior involvement procedure. Because the Court's opinion has been frequently restated and critiqued, I am not going to repeat it in detail. I will also refrain from elaborating on the critical assessment of the CJEU's approach because it has already been done. The following analysis refers to the CJEU's remarks and critiques them only as far as it is necessary to consider the real consequences of its demands and possible methods of their realization.

\section{Coordination of the Two Minimal Standard Clauses}

The first point ${ }^{21}$ of the CJEU involves few practical complications, although its meaning might appear ambiguous. It concerns the necessity of coordinating two minimal standard

${ }^{21}$ Adhésion, Case 2/13 at para. 179-90. 
clauses-from Article 53 of the Charter of Fundamental Rights ${ }^{22}$ and coincidentally Article 53 ECHR. The former stipulates that nothing in the Charter shall be interpreted as restricting or adversely affecting human rights and fundamental freedoms as recognized in their respective fields of application, by EU law and international law and by international agreements to which the EU or all the Member States are party, including the ECHR, and by constitutions of the Member States. According to Article 53 ECHR, nothing in the Convention shall be construed as limiting or derogating from any of the human rights and fundamental freedoms ensured under the laws of any High Contracting Party or under any other agreement to which it is a party.

\section{Conclusions of the First Point}

The CJEU apparently found it plausible that-after the accession-Article 53 ECHR might be interpreted as a potential detriment to the primacy, unity, and effectiveness of EU law-hence the necessity of coordination. This conclusion draws from CJEU's judgment in Melloni, ${ }^{23}$ where the CJEU clearly delimited the scope of application of Article 53 CFR by national courts. The case concerned inter alia the possibility of a national court refusing to surrender a person against whom a European Arrest Warrant (EAW) has been issued if the penal procedure in the requesting Member State didn't meet the human rights standard protections granted by the constitution of the executing Member State.

The Spanish Constitutional Court, which made a request for a preliminary ruling in Melloni, attempted to use the clause of minimal standard from Article 53 CFR to justify such refusal. Prima facie this provision-allowing of raising the standard of protection at the national level-might appear justified, yet its usage would render Framework Decision $2002 / 584 / \mathrm{JHA}^{24}$ that established the EAW, inoperative. Every surrender demanded by the requesting State might be blocked for shortcomings in the level of human rights protection of the requesting State by a national court in the executing State. Given all the differences between human rights provisions in Member States, even the mere possibility of such refusal would lead to effective paralysis of the EAW surrender procedure. National courts would have to compare the protection in two countries. Consequently, the Court stated in Melloni that:

It is true that Article 53 of the Charter confirms that, where an EU legal act calls for national implementing

\footnotetext{
22 See Charter of Fundamental Rights of the European Union (consolidated version), Dec. 7, 2000, 2016 O.J. (C 202) 389 [hereinafter CFR].

${ }^{23}$ See Case C-399/11, Stefano Melloni v. Ministerio Fiscal (Feb. 26, 2013), http://curia.europa.eu.

${ }^{24}$ Council Framework Decision 2002/584/JHA, on the European arrest warrant and the surrender procedures between Member States, Jun. 13, 2002, 2002 O.J. (L 190) 1.
} 
measures, national authorities and courts remain free to apply national standards of protection of fundamental rights, provided that the level of protection provided for by the Charter, as interpreted by the Court, and the primacy, unity and effectiveness of EU law are not thereby compromised. ${ }^{25}$

Even though the clause of minimal standard from the CFR had been safeguarded in Melloni against its usage contrary to EU law principles, the Court noticed in Opinion 2/13 that there is a potential threat in the analogical clause from the ECHR. ${ }^{26}$ Such a misgiving was not, however, sufficiently explained by the CJEU. The accession will not repeal Article 53 CFR nor its understanding imposed by Melloni, so this provision will be in force parallel to Article 53 ECHR in the scope of application of EU law. Given that de facto all rights from the ECHR are already included in the CFR, it is not possible to apply the former without applying the latter. It might be argued that the interpretation from the Melloni judgment will ipso facto encompass all applications of Article $53 \mathrm{ECHR} .{ }^{27}$ Just as the principles of primacy, unity, and effectiveness of EU law apply to Article $53 \mathrm{CFR},{ }^{28}$ so must they apply to Article $53 \mathrm{ECHR}$ after the accession because the Convention will occupy a mezzanine rank between primary and secondary law. ${ }^{29}$

Moreover, the ECHR-and case law of the ECtHR ${ }^{30}$ - will not entitle the Member States to disregard principles of EU law, but it will create a minimum standard of human rights

\footnotetext{
${ }^{25}$ Melloni, Case C-399/11 at para. 60.

${ }^{26}$ Adhésion, Case 2/13 at para. 189.

${ }^{27}$ Cf. Ingolf Pernice, L'adhésion de l'Union européenne à la Convention européenne des droits de l'homme est suspendue. Remarques à propos de un avis surprenant de la Cour de Justice de l'Union européenne du 18 décembre 2014, 51 CAH. DR. EUR. 59 (2015).
}

${ }^{28}$ See Eleanor Spaventa, The Protection of Fundamental Rights in the European Union after Opinion 2/13, $22 \mathrm{MJECL}$ 47 (2015).

${ }^{29}$ Charalambos Tsiliotis, Das Verhältnis zwischen den Europäischen Gerichtshofen in Luxemburg und Straßburg vor und nach dem Beitritt der Europäischen Union zur EMRK, in DER BEITRITT DER EUROPÄISCHEN UNION ZUR EMRK/THE ACCESSION OF THE EUROPEAN UNION TO THE ECHR/L'ADHÉSION DE L'UNION EUROPÉENNE À LA CDDH 83 (Julia IliopoulosStrangas, Vasco Pereira da Silva \& Michael Potacs eds., 2011); Rainer Arnold, Der Schutz der Grundrechte in Europa vor und nach dem Beitritt der Europäischen Union zur EMRK: Auswirkung auf Deutschland, in Id. at 188; Paul Gragl, The Accession of the European Union to the European Convention on Human Rights 98 (2013); Walter Obwexer, Der Beitritt der EU zur EMRK: Rechtsgrundlagen, Rechtsfragen und Rechtsfolgen, 47 EuR 143 (2012); Paolo Mengozzi, Les caractéristiques spécifiques de l'Union européenne dans la perspective de son adhésion à la CDDH, 15 IL DIRITTO DELL'UNIONE EUROPEA 241 (2010).

${ }^{30}$ Lambrecht, supra note 7, at 186-87. 
protection. ${ }^{31}$ If a national court interprets the minimal standard clause from ECHR analogically to the path taken by the Spanish Tribunal Constitucional in Melloni, Article 53 ECHR itself would not stand in its way, but such a step would still be tantamount to infringing Article 53 CFR-whose interpretation was clearly delimited by the CJEU-as well as some basic principles of EU law. ${ }^{32}$ Therefore, the threat seems purely speculative because sufficient safeguards against such usage of Article $53 \mathrm{ECHR}$ will be operative after the accession without any further regulations. ${ }^{33}$

\section{Solutions}

Contrary to what one could expect from nearly unanimous skepticism concerning this point of the Court, the realization of the exact demand of the CJEU does not pose too much difficulty. Taken literally, this part of the Opinion demands that there be some coordination between Article 53 CFR and Article 53 ECHR with respect to the rights recognized by the Charter that correspond to those guaranteed by the Convention. Because the Court found the DAA lacking, it is evident that a new provision is necessary to safeguard such coordination. The CJEU does not provide the exact way of coordinating the CFR's and the ECHR's minimal standard clauses, creating wide latitude for the negotiators of the future draft.

\subsection{Preliminary Considerations}

Two main questions must be addressed before the relevant provision might be proposed. Firstly, it must be decided whether the clause should be included in the future draft of the AA or whether it should be a subject of declarations of the Member States and perhaps also the EU. The second option has found some supporters who seem to perceive it as a simpler and more flexible solution. ${ }^{34}$ This point of view, however, relies on a minimalist approach and assumes that the fewer modifications to the current DAA, the better chance it stands in the negotiating process-because the DAA was already accepted by the non-EU parties to the ECHR-and CJEU review. As the envisioned scope of necessary amendments to the DAA is broader today than it appeared directly following Opinion $2 / 13$, the option of cosmetic

\footnotetext{
${ }^{31}$ See Eeckhout, supra note 7, at 967; CMLR Editorial Comments, supra note 4, at 11; Halberstam, supra note 5, at 105. Jean-Paul Jacqué, however, approved the CJEU's stance in this regard, although with little substantive explanation of the threat posed by Article 53 ECHR. Jacqué, supra note 5.

32 See Halberstam, supra note 5, at 125.

${ }^{33} \mathrm{See}$ There might be another way of understanding the Court's stance. The CJEU might fear a situation in which a national court could refer to Article 53 ECHR through the so-called horizontal clause from Article 52, paragraph 3 CFR and thus circumvent the safeguards from Melloni. The horizontal clause, however, applies only to rights stipulated by the Convention and not to all of its provisions. Consequently, such interpretation would not be admissible.

${ }^{34}$ See Pernice, supra note 27, at 60; Krenn, supra note 5, at 166.
} 
changes supplemented with a wide range of unilateral declarations no longer appears feasible. On the contrary, a thoroughly reconsidered new draft might be the only way to avoid the repetition of the " $2 / 13$ scenario." The danger of non-EU parties to the ECHR rejecting the new draft, although non-negligible, shouldn't be overestimated because-at least in the case of this point-the envisioned provision will address only specific demands of EU law and should not be of concern to the Accession Agreement parties which do not belong to the EU.

There are also better legal arguments to support the first option, namely amending the DAA itself. Even though the negotiators already partially resorted to the technique of "outsourcing" the DAA to a unilateral declaration and memoranda of understanding, it is not desirable to turn the exception into the rule. This method of legislation should be subsidiary to preparing one coherent agreement because the diversity of norms regulating the participation of the EU and its Member States in the ECHR system might provoke future ambiguities in interpretation. The status of unilateral acts in international law is distinct from international agreements; generally applicable norms governing their validity, force, and consequences are more scarce and vague than in the case of international agreements. If they are used abundantly in the framework of the DAA, the legal certainty of this system will be weaker in comparison to a system composed only of the DAA-or at least with few declarations which are necessary. Moreover, declarations are methods of regulation based on international law rather than EU methods of legislation, which in this case would prefer general treaty norms. Unilateral declarations are used in the treaty system mainly to declare reservations of Member States, not to guarantee a general effect. Finally, numerous declarations will needlessly complicate the legal regulations of the accession. If national courts-which will be primary recipients of the provision in question-are to be aware of this coordination clause, it belongs in the DAA and not to an immense catalogue of attachments to it.

These arguments indicate that the declaration option, although seemingly more feasible, might entail future interpretative complications. While inserting a coordination provision into the DAA cannot by itself provoke future criticism from the CJEU apart from the Court's possible negative view on the substantive content of such a provision, the approach of the Court might not be predictable in the case of declarations. Even though the wording of the relevant part of Opinion $2 / 13$ is vague and seems to allow various methods of realization, the declaration option is less certain than the DAA option. In this regard, there seems to be no significant difficulties with amending the DAA, so this alternative appears safer.

Additionally, the exact wording of the coordination provision demanded by the Court must be determined. Contrary to what might appear prima facie, the material content of the regulation in question does not pose much difficulty. There are only two potential hardships which need to be considered. The first one concerns the fact that this point is couched in imprecise terms, which leaves considerable latitude for the Court in the future review of the next DAA. Surely it might be a blessing because the CJEU will be able to adopt a more 
moderate stance without contradicting itself, but simultaneously it will not be difficult to declare that the provision does not meet the demands of Opinion 2/13. As the future reaction of the Court is hard to determine, it shouldn't be a subject of current concern if only the coordination provision is formulated with adequate meticulousness.

The second hardship, however, is more concrete but also more challenging. If the coordination provision becomes part of the DAA, it will also be an integral part of the ECHR. As such, it will be subject to interpretation by both the ECtHR and the CJEU, becoming a potential clashing point. Consequently, the coordination provision demanded by the CJEU will be open to interpretation by the ECtHR during its adjudication on the merits of individual applications and, even more importantly, on their admissibility. This situation, however, might be a legal minefield. The question at stake is whether the ECtHR would be entitled to refer to such a clause while it determines the admissibility of an application. Superficially, it might appear tempting to link the coordination clause with admissibility criteria and thus guarantee that-if any national court attempted to use Article 53 ECHR in a way similar to the one suggested by the Spanish Constitutional Tribunal-the ECtHR would find the application inadmissible, thereby strengthening the primacy and unity of EU law. ${ }^{35}$

Nevertheless, this seemingly advantageous solution poses a real threat to the values listed by the CJEU in its demand to establish the coordination clause apart from its feasibility in the context of granting the EU an unjustified privilege which other parties to the ECHR don't enjoy. If the ECtHR were to interpret the compliance of the decision being a subject of application with the coordination clause, it would have to assess whether the demands specified by the CJEU in Melloni were met in each case. In Opinion 2/13, read alongside Melloni, the CJEU did not exclude the possibility of national courts referring to Article 53 ECHR in the scope of application of EU law, but fortified such application against posing a threat to principles of primacy, unity, and effectiveness. It imposed upon national courts the need to undertake a special test determining whether their referral to Article $53 \mathrm{ECHR}$ is compliant with these principles. Consequently, if the coordination clause were subject to interpretation of the ECtHR, this Court would have to assess whether this test was satisfactorily completed. This would give the ECHR the right to interpret basic principles of EU law, which remains one of the most dreaded options for the CJEU.

It seems manifestly discordant with EU law to explicitly link the coordination clause with conditions of admissibility of applications to the ECtHR. It is not certain whether inserting this clause into the DAA poses the same threat, albeit implicitly. Article 35, paragraph 3(a) ECHR stipulates that any individual application which is incompatible with the provisions of the Convention or the Protocols thereto shall be declared inadmissible by the ECtHR.

${ }^{35}$ Such a proposal was, in fact, propounded in the literature. Cf. Maciej Taborowski, Poziom ochrony praw podstawowych wynikajqcy z Karty Praw Podstawowych UE jako przeszkoda do przystapienia Unii Europejskiej do Europejskiej Konwencji Praw Człowieka, 12 EUROPEJSKI PRZEGLĄD SĄDOWY 33 (2015). 
Naturally, the future interpretation of this criterion regarding the DAA is hard to foresee, but, at this point, nothing precludes the possibility of understanding the Agreement as functionally equivalent to Protocols to the ECHR. As the CJEU's approach indicates, it seems well-advised, if not necessary, not to rely upon the good will of the ECtHR and to eliminate all possible loopholes in the DAA which might-even theoretically-be detrimental to the autonomy of EU law. The status of the coordination clause in relation to Article 35, paragraph 3(a) ECHR should be scrutinized in search of fields of possible clashes of the two courts. Perhaps another provision in the DAA which would explicitly exclude this clause from the ambit of the above-cited admissibility criterion would suffice. Yet given that it might not be the only provision to which this threat could apply, a general clause on the relation between Article 35, paragraph 3(a) ECHR and the DAA would be more advisable-also regarding the technique of legislation. It might be argued that the declaration option would better resolve this problem, but the ECtHR is not prohibited from interpreting such a declaration as part of overall law of the ECHR. Therefore, it seems more reliable to determine the status of some of the DAA clauses in a separate provision.

\subsection{Possible Wording of the DAA Clause}

Formulating the exact wording of the coordination clause does not seem to be an arduous task, which does not mean that the solution is unambiguous. Tobias Lock already proposed one possibility: "Article 53 of the Convention shall not be interpreted as requiring the EU's Member States to provide a higher domestic standard of human rights protection than that provided for by the Convention." ${ }^{36}$ This proposal, however, is not a true coordination clause as it doesn't refer to criteria from Melloni. Moreover, it does not seem to contain any new normative content because Article 53 ECHR states that the ECHR does not limit the possibility of providing a higher standard of protection by the parties, thereby explicitly leaving the decision to raise standards to the discretion of the States. The real demand of the CJEU consists not in blocking the ECHR's requirement to raise standards of protection-because it doesn't exist and won't exist after the accession-but in coordinating Article 53 ECHR with Article 53 CFR.

There are two paths here. Article 53 CFR has an inherent limitation of its scope because, according to Melloni, applying Article 53 CFR in a way which poses a threat to principles of EU law violates Article 53 CFR itself. Therefore, this limitation might either be transplanted into Article $53 \mathrm{ECHR}$, in which case such an application posing a threat to principles of EU law would infringe Article 53 ECHR as well. Alternatively, it might be laid down as an external limitation. In the latter option, applying Article 53 ECHR which could be detrimental to the primacy, unity, or effectiveness of EU law would be, in the scope of EU law, a legitimate application of Article $53 \mathrm{ECHR}$, but it would be tantamount to infringement of the coordination clause.

${ }^{36}$ See Lock, supra note 7, at 257. 
The former option seems to better safeguard the coordination in question, but it constitutes a broader invasion into law of the ECHR. Moreover, it would be much more difficult, if not impossible, to exclude the inherent limitation of Article $53 \mathrm{ECHR}$-with references to EU law-from the interpretation of ECtHR. Therefore, the latter option should be followed. The clause might have the following wording: "In the scope of application of EU law, Article 53 of the Convention may be applied by the Member States only if it shall not infringe Article 53 of the Charter of Fundamental Rights interpreted in the light of principles of [EU] law." Naturally, the clause might omit the reference to Article 53 CFR and mention only principles of primacy, unity, and effectiveness, but the proposed option avoids introducing explicit terms of EU law into the DAA, thereby minimizing the risk of the ECtHR undertaking inopportune interpretation of EU law.

\section{Principle of Mutual Trust Around Freedom, Security, and Justice}

The second point in which the DAA isn't compliant with EU law-according to the CJEU-is much more ambiguous. ${ }^{37}$ The Court points out that the DAA assumes the equality of parties to the ECHR in relations between the EU and non-EU parties to the Convention, the EU and its Member States, and among Member States. This assumption, however, disregards the special relations between all the "EU parties" - namely the EU itself and its Member Stateswhich are based on the principle of mutual trust. In the context of the application of the ECHR, this principle precludes Member States from ascertaining whether another Member State has observed fundamental rights.

\section{Conclusions of the Second Point}

\subsection{The Difference of Standards Between the CJEU and the ECtHR}

According to a majority of commentators, this point of the Opinion alludes to a marked difference in approaches adopted by the CJEU and the ECtHR in regard to fundamental rights violations consisting in exposing the victim to possible or real violations perpetrated in another state, most notably in case of surrendering or transferring a person. ${ }^{38}$ Whenever such violations are declared between EU Member States and in the scope of applying EU law, a Member State might be confronted with conflicting obligations. On the one hand, EU law-and most notably the principle of mutual trust-stipulates that it should abstain from controlling the level of protection in another Member State. On the other hand, it runs the risk of indirectly infringing fundamental rights if that Member State eventually violates the rights of a surrendered person.

${ }^{37}$ Adhésion, Case 2/13 at para. 191-95.

${ }^{38}$ See Eeckhout, supra note 7, at 968; CMLR Editorial Comments, supra note 4, at 8-9; Halberstam, supra note 5, at 126-30; Lambrecht, supra note 7, at 187. 
The CJEU proposed a compromise in the N.S. case ${ }^{39}$ through the doctrine dubbed "horizontal Solange." 40 It allows testing the protection only when "systemic" infringements take place in another Member State. ${ }^{41}$ Particular violations-whose occurrence does not reach this threshold-are shielded by a Solange-like presumption deduced from the principle of mutual trust. The ECtHR, however, is not bound by this principle, adopted in M.S.S. ${ }^{42}$ and Tarakhel, ${ }^{43}$ a higher standard which demands that the testing should occur even in particular cases with no systemic character. ${ }^{44}$ This difference in standards was aggravated by the lack of application of the Bosphorus presumption in the last cited cases. Therefore, it seems that the CJEU demanded that the DAA defend its own standard against the one of the ECtHR. Such an approach might be surprising given that the difference of standards affects principles of EU law regardless of the accession, which in this regard seems to act only as a pretext. Yet the Court might have perceived the necessity of concluding the $A A$ as a unique occasion to hold off a potential danger for autonomy of EU law.

${ }^{39}$ See Case C-411/10 \& C-493/10, N. S. vs Secretary of State for the Home Department and M. E. et al. v. Refugee Applications Commissioner Minister for Justice, Equality and Law Reform, 2011 E.C.R. I-13905, para. 119-20. See also Patrick Birkinshaw, How European Union Developments in Human Rights' Protection are Changing and Will Change the Context of Human Rights' Protection within the United Kingdom, in DER BEITRITT DER EUROPÄISCHEN UNION ZUR EMRK 256-64; Jean-Paul Jacqué, The Charter of Fundamental Rights and the Court of Justice of the European Union: A First Assessment of the Interpretation of the Charter's Horizontal Provisions, in THE EU AFTER LISBON. AMENDING OR CoPING WITH THE EXISTING TREATIES? 153 (Lucia Serena Rossi \& Federico Casolari eds., 2014).

${ }^{40}$ See Iris Canor, My Brother's Keeper? Horizontal Solange: An Ever Closer Distrust Among the Peoples of Europe, 50 CMLR 385, 395-99 (2013).

${ }^{41}$ N.S., Case C-411/10 \& C-493/10 at para. 86.

${ }^{42}$ M.S.S. v. Belgium and Greece, 2011 I Eur. Ct. H.R. 255.

${ }^{43}$ Tarakhel v. Switzerland, App. No. 29217/12, (Nov. 4, 2014), http://hudoc.echr.coe.int/.

${ }^{44}$ Potential clashes between the principle of mutual trust and obligations stemming from the ECHR are not limited to surrender and transfer cases, but also to recognition of civil rulings. In the recent Avotins v. Latvia case, the ECtHR remarked: "[W]here the courts of a State which is both a Contracting Party to the Convention and a Member State of the European Union are called upon to apply a mutual recognition mechanism established by EU law, they must give full effect to that mechanism where the protection of Convention rights cannot be considered manifestly deficient. Nevertheless, if a serious and substantiated complaint is raised before them to the effect that the protection of a Convention right has been manifestly deficient and that this situation cannot be remedied by European Union law, they cannot refrain from examining that complaint on the sole ground that they are applying EU law." Avotiňs v. Latvia, App. No. 17502/07, para. 116 (May 23, 2016), http://hudoc.echr.coe.int/. In this case, the potential difference of standards was masked by the application of the Bosphorus presumption. Parenthetically, the ECtHR in its judgment explicitly cited Opinion 2/13 in a manner which seems to belie its will of reaching a compromise. 


\subsection{The Current CJEU's Standard: The Aranyosi \& Căldăraru Case}

In this context, it must be mentioned that the CJEU's approach-so far most clearly expressed in N.S. - has been recently restated in Aranyosi \& Căldăraru. ${ }^{45}$ The ruling refers to the Opinion directly, so it sheds some light on the Court's reasoning. Moreover, the current legal context of the future amendments of the DAA has changed slightly, so it is necessary to present this ruling. In both cases, courts (from Hungary and Romania) issued EAWs for the defendants. Both defendants were subsequently arrested in Bremen. Yet the Oberlandesgericht in Bremen, adjudicating their surrender, found that there were substantive doubts (backed up, among others, by the ECtHR's judgments) concerning the human rights standard of executing detention in Hungary and Romania. With a possible systemic infringement of human rights, the Oberlandsgericht referred this to the CJEU for a preliminary ruling on the necessity of surrender and the admissibility of demanding guarantees of compliant detention standards.

The CJEU reiterated that the Framework Decision system is based on the principle of mutual trust. Referring to Opinion 2/13, it once again stated that "the principle of mutual trust requires, particularly with regard to the area of freedom, security, and justice, each of those States, save in exceptional circumstances, to consider all the other Member States to be complying with EU law and particularly with the fundamental rights recognised by EU law." ${ }^{46}$ In its subsequent reasoning, however, the Court underscored the role of these "exceptional circumstances," particularly in the context of respecting values declared in the CFR and in the ECHR. If a national court "is in possession of evidence of a real risk of inhuman or degrading treatment of individuals detained in the issuing Member State," ${ }^{47}$ it is bound to assess this risk, relying on general information provided, inter alia, by the ECtHR.

Such general information cannot, however, justify refusals to execute an EAW.

Whenever the existence of such a risk is identified, it is then necessary that the executing judicial authority make a further assessment, specific and precise, of whether there are substantial grounds to believe that the individual concerned will be exposed to that risk because of the conditions for his detention envisaged in the issuing Member State. ${ }^{48}$

\footnotetext{
${ }^{45}$ Case C-404/15 \& C-659/15, Aranyosi \& Căldăraru (Apr. 5, 2016), http://curia.europa.eu/.

${ }^{46}$ See id., at para. 78.

${ }^{47}$ See id., at para. 88

${ }^{48}$ See id., at para. 92
} 
The execution of the EAW may be refused only if the national court finds that the person whom the surrender concerns will run a "real" risk of inhuman or degrading treatment. ${ }^{49}$ Consequently, the refusal is admissible only in case of sufficiently proven and individualized risk of such a treatment.

The formula of "real risk" appeared already in N.S. ${ }^{50}$ it simply matches the similar condition formulated by the ECtHR in its numerous judgments. ${ }^{51}$ The relative novelty of Aranyosi \& Căldăraru consists then in something different: The Court developed the obligations imposed on national courts extensively, even when they are currently bound to undertake the closest possible scrutiny of the individualized risk of maltreatment. Although the obligations didn't change substantially, the demanded level of assessment seems to have been increased. This move cannot be read other than as an attempt to bring the EU standard closer to the ECtHR's, which requires that a State carry out "a thorough and individualised examination of the situation of the person concerned." 52

Nevertheless, both standards cannot fully overlap for at least two reasons. First, the CJEU still perceives the refusal of transfer or surrender as permissible in "exceptional circumstances." The level of this exceptionality seems to be even higher than the one effectively established by the ECtHR's Bosphorus presumption, whenever that applies. In this light, Aranyosi \& Căldăraru can be seen as an attempt to have one's cake and eat it too. The increased level of demanded scrutiny doesn't necessarily mean that national courts would ultimately be empowered to refuse transfer or surrender as the ECtHR would require.

Second, the very functions of the two courts have different perspectives. The ECtHR declares violations which have already happened. This a posteriori perspective makes it easier to find omissions in the scrutiny already undertaken by national courts. On the contrary, the CJEU formulates its demands a priori for national courts. Consequently, meeting the CJEU's standard-even raised in Aranyosi \& Căldăraru-doesn't preclude that violations effectively occur and the ECHR declares responsibility.

For these reasons, the current relationship between the two standards is paradoxical. In practice, the CJEU did its best to level its standard with the one of the ECtHR. Nevertheless, the clash of approaches preserves the difference. For the CJEU, the principle of mutual trust takes precedence, so refusing cooperation because of possible human rights violations must remain exceptional. By contrast, the ECtHR human rights protection remains the central point of interest.

\footnotetext{
${ }^{49}$ See id., at para. 94.

${ }^{50}$ N.S., Case C-411/10 \& C-493/10 at para. 94.

${ }^{51}$ Cf. Tarakhel, App. No. 29217/12, at para. 93; M.S.S., 2011 I Eur. Ct. H.R. 255, at para. 365.

${ }^{52}$ Cf. Tarakhel, App. No. 29217/12, at para. 104.
} 


\section{Two Interpretations of the Second Point and Respective Solutions}

If Opinion 2/13 indeed alluded to the difference in standards of the two courts, it couched it in general terms. Consequently, this point might be interpreted twofold depending on whether the accent is on the clash of principles or clash of particular standards.

\subsection{The Narrow Interpretation: Imposition of Standard}

The narrow interpretation focuses on the apparent direct motive of the Court and aims at safeguarding the defense of the CJEU's standard after the accession. According to this interpretation, the revised DAA should contain a clause which would explicitly impose the CJEU's standard upon the ECtHR when scrutinizing both EU law and acts or omissions of Member States applying EU law. In other words, instead of guaranteeing that whenever EU law interpreted under the principle of mutual trust would force national authorities to transfer, surrender, or recognize the grounds of possible human rights violation, the clause in question would shield the EU and Member States from liablity for infringing the Convention. Principles of responsibility would remain untouched, but the practical possibility of their conflict would be eliminated.

Such a clause could read as follows:

Whenever Member States of the European Union act in application of the principle of mutual trust and fulfilled the demands of assessing the potential risk of violating the Convention in conformity with the requirements of European Union law as interpreted by the Court of Justice of the European Union, they shall not be held responsible for violating the Convention or Protocols thereto.

Because the very law of the ECHR would have to be amended, this option requires a clause in the Accession Agreement-neither unilateral declarations nor a reservation made by the EU have this effect. ${ }^{53}$

\footnotetext{
${ }^{53}$ Although a solution based on a reservation made by the EU on accession has been proposed in literature it cannot successfully realize the demands of the Court. Krenn, supra note 5, at 165 . The concept of a reservation in international law applies only to obligations of the EU, not to obligations of the Member States. Even if such a reservation could affect the application by Member States of the Convention as part of EU law only, it is irrelevant in this context because-from the international law viewpoint, which governs the eventual responsibility of Member States - their obligations would remain untouched. Consequently, such a reservation wouldn't shield Member States from the ECtHR's declaring their responsibility according to principles formulated in Soering.
} 
Although the solution in the narrow interpretation is seemingly humbler, it would be tantamount to an unprecedented direct intervention in case law of the ECtHR. From the point of view of international law, the parties to the Convention are eligible to limit its interpretation. This step, however, would not only constitute a hardly justifiable privilege for the Member States, ${ }^{54}$ but it would also challenge the position of the ECtHR. Moreover, it would limit the current scope of obligations imposed on Member States by the ECHR. The teleological aspect of such limitation isn't unambiguous because the EU Treaties don't give the principle of mutual trust a clear priority over human rights protection, ${ }^{55}$ although the Opinion 2/13 might suggest that the CJEU is convinced that they do. ${ }^{56}$

Setting aside all discussions on the status of the Convention as a self-contained regime and its level of constitutionalization, it cannot be forgotten that the Strasbourg Court might interpret the eventual clause differently than the CJEU's expectations or even-although much less probable-declare it invalid or make it practically inoperative. Therefore, the narrow interpretation-although it would demand less intervention into ECHR law-might provoke the ECtHR, through explicit curtailing of its case law, to take unprecedented steps. Finally, the clause would require that the ECtHR explicitly interpret EU law and case law of the CJEU, which itself constitutes a threat for autonomy of European law.

\subsection{The Broad Interpretation: Exclusion of the Soering-Based Responsibility}

In the broader interpretation, the CJEU would demand that within the scope of EU law no Member State could be held responsible for indirect violations based on the principle formulated in Soering. ${ }^{57}$ This step would explicitly exclude a considerable scope of Member States' acts from the purview of the ECtHR, although victims would still be entitled to file applications against states to which they were transferred or surrendered. Given that the Member States constitute more than a half of the parties to the Convention, it would probably weaken future judicial activism of the Strasbourg Court in the field of indirect responsibility.

\footnotetext{
${ }^{54}$ Such a clause would have to be perceived only as a direct consequence of EU interests. It cannot be motivated by the presumption that the CJEU effectively has a better interpretation of relevant norms of the ECHR. Cf. Steve Peers, The CJEU and the EU's Accession to the ECHR: A Clear and Present Danger to Human Rights Protection, EU LAW ANALYSIS, (Apr. 17, 2015), https://eulawanalysis.blogspot.co.uk/2014/12/the-cjeu-and-eus-accession-toechr.html.

${ }^{55}$ See Peers, supra note 7, at 221.

${ }^{56}$ See Lock, supra note 7, at 243.

${ }^{57}$ See Soering v. The United Kingdom, A-161 Eur. Ct. H. R. 217 (1989).
} 
If the broader interpretation is accepted, the solution might consist only in amending the DAA. Nevertheless, formulating the exact wording of the necessary clause is more difficult than in the case of the previous point of Opinion 2/13. Three options might be considered.

The first one, the most intuitive, involves the provision which excludes generally all responsibility of Member States based on the Soering principle, if the principle of mutual trust is involved. Tobias Lock proposed the following suggestion: "Member States of the EU cannot be held responsible under the Convention for failing to carry out a review of another Member State's compliance with Convention rights." ${ }^{58}$ This proposal, however, omits the crucial element: Limiting the clause to the scope of EU law. Even though it seems necessary-otherwise the DAA will contain an exclusion whose scope is broader than the one required by the CJEU, thereby needlessly restricting the effective application of the ECHR-it might prompt the ECtHR to interpreting the boundaries of EU law, which would be inadmissible from the point of view of the CJEU.

This problem, which applies to other solutions demanded by the Opinion, cannot be satisfactorily solved, let alone easily. Given the complexity of the issue and the fact that the CJEU did not elaborate on potential threats caused by provisions containing the restriction "within the scope of EU law," the problem might be disregarded in the hope that the ECtHR will not use them in conflict with the CJEU. Other solutions would demand additional complicated institutional links between the two courts. One can conceive of a special preliminary ruling of the CJEU on request by the ECtHR whenever such clauses would present interpretational problems. The procedure might be regulated as a special mode of the prior involvement proceedings. Nevertheless, the vicious circle would persist: If the ECtHR were to file a request only in case of interpretational problems, it would have to interpret EU law anyway to decide on the conditions of such a request. The vicious circle would be avoided only if the ECtHR must file a request whenever EU law could even be potentially applied in a given case, even if its scope and provisions would be manifestly unambiguous, or if some EU institutions-likely the Commission-were entitled to request the ECtHR to ask for preliminary ruling in a binding manner.

There are more specific problems with the solution consisting of the general exclusion of Soering-based responsibility of Member States. The first one concerns the inevitable resistance to such exclusion of non-EU parties to the ECHR. Thus far, it might be the strongest privilege for the EU parties granted by the AA-a privilege which cannot be accounted for by impeccable observation of human rights norms in all Member States. ${ }^{59}$ Consequently, this point of the Opinion will be the most difficult to negotiate as well as the probable need to exclude the Common Foreign and Security Policy (CFSP) from the ambit of the ECtHR jurisdiction.

\footnotetext{
58 See Lock, supra note 7, at 261.

${ }^{59} \mathrm{Cf}$. Spaventa, supra note 28 , at 51 .
} 
The second problem relates to the nature of international obligations that this exclusion would affect. Responsibility in the Soering-paradigm derives from the agreement of parties to observe rights and freedoms declared in the Convention. Because the accession does not change them by itself, a special clause in the AA will be necessary. This means that the scope of responsibility of Member States will be effectively confined through their withdrawal from previously binding obligations. It is not clear whether such act would be valid given that the Convention-according to the ECtHR-constitutes an erga omnes system of human rights guarantees. Consequently, even though the AA might eventually modify the ECHR, it is not certain whether the ECHR will allow a subsequent limiting of liability which cannot be deduced from any provision of the Convention itself and its Protocols.

These arguments demonstrate that the general exclusion might not be the most feasible solution. A more realizable and legally interesting alternative is to establish a Bosphorus-like presumption of conventionality of acts undertaken by Member States with regard to the principle of mutual trust in their relations with other Member States. ${ }^{60}$ Such a presumption stipulated by a relevant clause in the AA would de facto codify the approach of the CJEU in the area and bind the ECtHR. Even if it is considered an undue privilege for the EU, it would breed less resistance from other parties to the Convention than the general exclusion. More importantly, it would preserve the principal goal of the accession, which is development of human rights protection; major indirect violations would not be shielded from the external control of the ECtHR. The relevant clause might be worded as follows: "Member States of the EU cannot be held responsible under the Convention for failing to carry out a review of another Member State's compliance with Convention rights within the scope of EU law, unless the level of protection of Convention rights in this Member State was manifestly deficient." Such wording, drawing directly on the formula from Bosphorus, ${ }^{61}$ might be amended in various ways to better conform to the CJEU's expectations. For instance, the "manifestly deficient" level of protection might be supplemented or replaced with further premises-such as "systematically" or "generally" - following the conclusions of N.S. The words "manifestly deficient" could also be narrowed by specifying "major" or "regular" infringements. This proposal offers the best possible compromise between the demands of the CJEU and the reality of accession negotiations.

A third option would solve the issue not through exclusions from the scope of jurisdiction of the ECtHR, but through safeguarding. Whenever the principle of mutual trust might be at issue, the ECtHR could adjudicate only on the potential responsibility of the EU. If the EU is determined to uphold its standard of control in N.S.-like cases and, simultaneously, doesn't

\footnotetext{
${ }^{60}$ See Agnieszka Frąckowiak-Adamska, Akcesja Unii Europejskiej do Europejskiej Konwencji Praw Człowieka-ryzyko naruszenia zasady wzajemnego zaufania między państwami członkowskimi, 12 EUROPEJSKI PRZEGLĄD SĄDOWY 39 (2015).

${ }^{61}$ Bosphorus Hava Yollari Turizm Ve Ticaret Anonim Sirketi v. Ireland, 2005-VI Eur. Ct. H. R. 107, at para. 156.
} 
want to undermine the principle of mutual trust between Member States, it might claim the sole responsibility in such cases. Member States relying on the protection guaranteed in other Member States would not be responsible if they applied EU norms correctly and undertook the control of their partners only in cases explicitly allowed for by EU law. Cases in which Member States conformed to EU law but infringed on the standard of the ECtHR would lead to the EU accepting responsibility. The Member States where a victim was transferred and where their rights were violated may have to accept responsibility too. This sui generis substitution of the responsible party could be combined with the co-respondent mechanism. For example, whenever a Member State-acting within the scope of EU lawclaims responsibility based on the Soering principle for acts of another Member State, that Member State could be substituted by the EU in the proceedings.

This solution, although easier to accept by non-EU parties to the ECHR, would re-shape fundamental principles of ECtHR proceedings, which currently do not allow of party intervention. Nevertheless, if only the scope of application of such a substitution were sufficiently limited - for example only to the Area of Freedom, Security and Justice-it might be acceptable for the parties to the Convention.

A fourth option may exist. It is the most unconventional, but given the abundance of radical and desperate proposals following Opinion $2 / 13$, it doesn't appear completely impossible. This option skillfully uses the imprecise wording of the Court's opinion and-instead of directly intervening into the scope of obligation of Member States under the Convention-formulates a strictly formal clause which pays homage to principle of mutual trust, but does not stipulate its direct conclusions. The provision could have the following wording: "Nothing in this Agreement shall require the European Union or its Member States to perform an act or adopt a measure which would disregard the principle of mutual trust as part of European Union law."

Given that the Court's exact intentions are highly unclear, it is not certain whether the CJEU demanded a general or detailed provision. Opinion 2/13 allows both interpretations, so both a detailed clause excluding some acts of Member States from the scope of control of the ECtHR and a general clause formulated above might be justified. Given legal uncertainty and the effectiveness of the ECHR control system, it is desirable to adopt a more detailed clause which would neatly delimit all interventions into the scope of control of the Strasbourg Court. A general clause would have one significant advantage of a more political than legal nature. A clause such as the one proposed above might be too imprecise to be effectively applied. More importantly, it would formally relate only to the AA, not to the Convention itself, which imposes on Member States obligations already affecting the principle of mutual trust. The CJEU, however, linked the threat to this principle not with pre-accession application of the ECHR, but with the act of accession. Apparently, it attempted using the opportunity given by the DAA to protect already endangered interests of the EU, yet its ruse might be turned against the Court itself. The threat to the principle of mutual trust posed by the AA would be eliminated, but the current obligations imposed by the Convention on 
Member States wouldn't be annulled. If all the other options prove unworkable, this trick might formally conform to the Court's demands without reaching the underlying goal of the CJEU. Consequently, even though such a clause would provide a formal safeguard demanded by the CJEU, it would be, in practice, worthless because the AA won't affect the principle of mutual trust, contrary to the Court's convoluted argumentation. For this reason, it also doesn't seem to risk the ECtHR interpreting EU law.

It might be the only feasible-although, hardly satisfying-solution if the other options are not accepted in the negotiation process. If adopted, the CJEU will have an option to withdraw pragmatically from its strict demands. The clause proposed above would reconcile the verbal faithfulness to the Court's conditions with the actual inoperativeness of the new provision, which might prove more readily accepted by other parties to the ECHR. This farfetched option poses a threat to the autonomy of EU law by allowing the Strasbourg Court to adjudicate on the scope and content of the principle of mutual trust. Nevertheless, this point of Opinion $2 / 13$ is particularly difficult to actualize, so, if the other options fail, this may be the only possible compromise to save the accession process.

\section{Protocol No. 16 to the Convention}

The next point of Opinion $2 / 13^{62}$ concerns the relationship between Protocol No. 16 to the ECHR and the preliminary ruling procedure. The Protocol, upon its execution, will allow the highest courts and tribunals of Member States to request advisory opinions from the ECtHR on the interpretation of rights and freedoms from the Convention. Even though the EU itself is not currently acceding to the Protocol, granting such a right to the highest courts and tribunals of Member States might, according to the CJEU, adversely affect the success of preliminary rulings. As in the previous point of the Opinion, the Court effectively demanded that the AA eliminate the risk which isn't directly related to the accession. ${ }^{63}$

\section{Conclusions of the Third Point}

Once again, the Court's key point is unclear because it first refers to the general conflict between the Protocol and preliminary rulings and then describes a form of this conflict involving the prior involvement procedure. Consequently, at least two interpretations surface: A narrow and a broad one.

\subsection{The Narrow Interpretation: Prior Involvement and Protocol No. 16}

The narrow interpretation concentrates on the link between the prior involvement procedure and Protocol No. 16. The Court's concerns relate to a scenario when a request for

\footnotetext{
62 See Adhésion, Case 2/13 at para. 196-99.

${ }^{63}$ See Eeckhout, supra note 7, at 971.
} 
an advisory opinion by a national court or tribunal triggers the prior involvement procedure. Because the CJEU's ruling issued is not binding on the ECtHR, the CJEU fears that the national court might follow the ECtHR's opinion even if it diverges from the previous ruling of the CJEU.

This concern seems dubious for at least two reasons. First, it is hard to negate the binding force of the CJEU's rulings for the national court in this scenario. Whenever the CJEU interprets EU law during proceedings prescribed by the Treaties, courts and tribunals of Member States must follow this interpretation when acting within the scope of EU law. Therefore, they cannot follow the ECtHR's opinion while disregarding the CJEU's ruling. ${ }^{64}$ The only lacuna in this reasoning might appear if the prior involvement procedure is not based-on the EU side-on proceedings prescribed by the Treaties, though this hardly conforms to EU law.

The second reason concerns the link between the prior involvement procedure and the corespondent mechanism. ${ }^{65}$ The procedure cannot be set off without the mechanism, whereas the mechanism is explicitly provided for only in case of "applications" (Article 3, paragraphs 2-4 DAA), not requests for preliminary opinions. Consequently, the current wording of the DAA excludes the threat mentioned by the CJEU, unless the ECtHR would err so far in its interpretation that it would autonomously, with no regard to the EU's stance, trigger the prior involvement procedure during advisory opinion proceedings. Nevertheless, if any solution to this concern of the Court can be proposed, it might rely on introducing a clause to the AA which explicitly precludes triggering the prior involvement procedure after a request for advisory opinion has been filed. Another, though more-risky option, consists of designing a special kind of prior involvement procedure geared toward the advisory opinion proceedings. In this case, the AA could expressly reiterate that the CJEU's rulings issued during this procedure would bind national courts and tribunals.

Although in this point of the Opinion, the Court provided only one concrete example of the threat posed by the Protocol No. 16 for EU law, its tone indicates that-contrary to previous points-general concerns are more important for the CJEU than one particular example-a seemingly hastily outlined conclusion. Consequently, the broader interpretation seems more adequate to the Court's intentions.

\subsection{The Broad Interpretation: Preliminary Rulings and Protocol No. 16}

The broad interpretation concerns not only-or even not at all-the prior involvement procedure, but general safeguards against threats to effectiveness of preliminary rulings. The CJEU seems to be concerned about a situation when a national court or tribunal could

\footnotetext{
${ }^{64}$ See Lock, supra note 5.

${ }^{65}$ See Lock, supra note 7, at 262-63.
} 
request an advisory opinion from the ECtHR instead of asking the CJEU for preliminary ruling, ${ }^{66}$ which could happen especially when applying the CFR insofar as its rights overlap with the ones from the ECHR. National courts and tribunals would thus have a possibility of pitting the ECtHR against the CJEU. ${ }^{67}$ This concern received justified criticism. Critics pointed out that both Article 267 Treaty on the Functioning of the European Union ${ }^{68}$ and CJEU case law-especially the conditions formulated in CILFIT ${ }^{69}$ - when applied to this circumstance will not be affected by the Protocol No. 16 let alone by the accession, ${ }^{70}$ which establishes the institution of an advisory opinion as optional and the opinion itself as non-binding. ${ }^{71}$ Therefore the CJEU's stance belies its distrust in national courts ${ }^{72}$ and a marked tendency to acquire interpretative priority over the ECtHR. ${ }^{73}$ Nevertheless, the demands of the CJEU must be met in the future DAA.

The Court alluded that it is necessary to amend the DAA to include a provision regulating the relationship between the mechanism established by Protocol No. 16 and the preliminary ruling procedure. Nevertheless, even if the broad interpretation is accepted, it is not evident how this relationship should be determined. Imprecise remarks of the CJEU allow several interpretations which entail different solutions.

\section{Solutions to the Third Point}

\subsection{Exclusion of Application of Protocol No. 16}

The most far-reaching interpretation would link the Court's concern with precluding national courts from requesting ECtHR guidance whenever the question falls into the ambit of EU law. ${ }^{74}$ Undoubtedly, such an exclusion guarantees that the current model of CJEU preliminary rulings will not be endangered by Protocol No. 16, which would simply not apply

${ }^{66} \mathrm{Cf}$. Halberstam, supra note 5 , at 121

${ }^{67}$ See id., at 122 .

${ }^{68}$ See Treaty on the Functioning of the European Union (consolidated version), Mar. 25, 1957, 2016 O.J. (C 202) 47 [hereinafter TFEU].

${ }^{69}$ Case 283/81, CILFIT v Ministero della Sanità, 1982 E.C.R. 3417, para. 16.

70 Just as in the case of the previous point of the Opinion, the CJEU seems to seize the opportunity created by the DAA to remove a general problem in relationship between the ECHR and EU law, not necessarily related to the accession itself.

${ }^{71}$ See Lock, supra note 5.

${ }^{72}$ See Jacqué, Pride and/or Prejudice?, supra note 5, at 25-27.

${ }^{73}$ See Krenn, supra note 5, at 156.

${ }^{74}$ Lock, supra note 7, at 263; Jacqué, Pride and/or Prejudice?, supra note 5, at 26. 
to all cases where it could clash with preliminary rulings. This solution is radical because it renders the Protocol inoperative in a wide range of cases before national courts. ${ }^{75}$

Apart from slim chances for its acceptance by the parties to the Convention, this seemingly easy option might turn out difficult to be effectively carried out. It is burdensome to link the delimitation "within the scope of EU law" with the content of a request to the ECtHR. Although Article 1, paragraph 2 of Protocol No. 16 stipulates that the request might be made only in the context of a case pending before a national court or a tribunal, it cannot concern the concrete ruling, but rather "questions of principle relating to the interpretation or application" (Article 1, paragraph 2) of the Convention rights and freedoms. ${ }^{76}$ This provision-apart from its future interpretation by the ECtHR-presumes that a request must be of a sufficient level of generality, so that conclusions of a subsequent opinion apply, at least potentially, to other cases and become part of a judicial dialogue between the Strasbourg Court and national courts in the area of human rights. ${ }^{77} \mathrm{~A}$ question arises whether such delimitation can be related to a general request for interpretation of the ECHR if the possibility of requesting the ECtHR is excluded within the scope of EU law. All rights and freedoms safeguarded by the Convention might be relevant in the context of EU law, so a general question itself cannot be classified as belonging to the scope of application of EU law or not. In light of this incomparability, the only coherent solution would be to rule out the application of Protocol No. 16 for all Member States, regardless of the boundaries of EU law. Nevertheless, then the Protocol would hardly make any sense.

If this delimitation concerned the law applicable in each case and made the request inadmissible whenever any provisions of EU law were applied by the national court, the exclusion would disregard the very construction of advisory opinions. As the ECtHR itself highlighted, "[t]he Court should not be called upon to review the facts or the national law in the context of this procedure." ${ }^{78}$ Whether the law applicable in a given case consists only of norms of national origin or whether it also contains norms of EU law remains irrelevant for

\footnotetext{
75 The reaction of the CJEU might be surprising given that during preparatory works on Protocol No. 16 advisory opinions were mentioned as means to guarantee the principle of autonomy of EU law, because the CJEU might avail of requesting the ECtHR. Cf. THE ECTHR REFLECTION PAPER ON THE PROPOSAL TO EXTEND THE COURT'S ADVISORY JURISDICTION para. 10 (Apr. 6, 2016), https://www.coe.int/t/dgi/brighton-conference/Documents/Court-Advisoryopinions_en.pdf.

76 See also EXPLANATORY REPORT to Protocol No 16 para. 9 (Jul. 10, 2013), http://www.echr.coe.int/Documents/Protocol_16_explanatory_report_ENG.pdf.

77 The ECtHR explicitly referred to this dialogue ECtHR as one of the goals of the Protocol. Cf. OPINION OF THE COURT on DRAFt PROTOCOL NO. 16 TO THE CONVENTION EXTENDING ITS COMPETENCE TO GIVE ADVISORY OPINIONS ON THE INTERPRETATION OF THE CONVENTION para. $\quad 4$ (May 6, www.echr.coe.int/Documents/2013_Protocol_16_Court_Opinion_ENG.pdf.

78 See id., at para. 8.
} 
the matter of the request. The requesting court should consider the context of EU law and formulate a question of a general character.

Moreover, such an exclusion cannot rule out that conclusions of an advisory opinion issued by the ECtHR in an earlier case where EU law was not applicable, and could not clash with the CJEU's preliminary ruling in a next case. As the jurisdiction of both European courts overlap, the exclusion of application of Protocol No. 16 in the Member States can hardly be restricted to the scope of EU law. Finally, even if such a confinement were accepted, the ECtHR would solely assess the admissibility of a request, so the Strasbourg Court would again be called upon to adjudicate on EU law in an inadmissible manner.

Another complication concerns the scope of exclusion not in relation to EU law, but to ECHR law. According to the approach adopted in the last two negotiations, the EU is going to accede-besides the Convention itself-to two Protocols "of the common denominator" namely Protocols No. 1 and 6. If anything, the EU won't be bound by Protocols No. 4, 7, 12, and 13. From the theoretical point of view, the accession shouldn't modify the legal position of these Protocols, so it seems sensible to confine the exclusion of application of Protocol No. 16 solely to the rights declared in Protocols No. 1 and 6. Nevertheless, this argument reveals that the accession and execution of Protocol No. 16 have little, if anything, in common, and the CJEU linked them only in order to find means to shield EU law from possible threats from advisory opinions. If the exclusion concerns-apart from the Convention-only Protocols No. 1 and 6, rights declared there and interpreted by the ECtHR in advisory opinions may still differ from rights from the CFR interpreted by the CJEU. Consequently, as far as the potential conflict between advisory opinions and preliminary rulings is concerned, there seems to belittle difference between the two groups of Protocols. Given that the CJEU itself did not refer to this problem, it remains unclear whether the exclusion should apply to all Protocols or only to these ones to which the EU accedes. The logic of the Court's argument-however feeble would be its real link with the accession-seems more compatible with the exclusion concerning all Protocols.

All the aforementioned arguments support the claim that any exclusion of Protocol 16's application would involve all courts and tribunals of the EU Member States, both within and outside the scope of EU law. This solution would radically undermine the ratification of the Protocol and stands little chance of acceptance by parties to the ECHR. If introduced, it will detract from the image of the EU as a human rights protector. Nevertheless, it is worth noticing that such a radical step is not demanded explicitly by the CJEU. Given that the exclusion of Protocol No. 16's application within the scope of EU law would entail a total exclusion, all solutions based on clauses which guarantee disapplication of the Protocol by national courts and tribunals should be used as a last resort. 


\subsection{Other Solutions to the Third Point}

There are other options which are not based on excluding the Protocol's application, but concentrate on providing sufficient coordination between the procedures of advisory opinions and preliminary rulings. Even though-as mentioned above-the entry into force of Protocol No. 16 establishing facultative advisory opinions shouldn't undermine the position of preliminary rulings in EU law, a supplementary clause might provide a foothold for coordination between the two if introduced into the future AA.

Various solutions exist. The simplest one consists of adopting a clause which affirms that those requests for advisory opinions cannot modify obligations imposed by EU law which oblige the highest courts and tribunals of Member States to ask for preliminary rulings. Such a clause would have little legal importance, but it would guarantee that the relationship between preliminary rulings and advisory opinions is recognized by Member States and requesting the latter cannot be detrimental to obligations prescribed by Article 267 TFEU. Adopting such a provision would be more valuable politically than legally because it would not change the status quo, but allows for milder consequences stemming from Opinion 2/13 for the CJEU.

If deemed too artificial, other solutions exist. It would be imaginable to legally link the execution of requests for advisory opinions with the necessity of preemptive request for a preliminary ruling on the same matter. ${ }^{79}$ In other words, filing a request to the ECtHR would be possible only after a preliminary ruling would be issued. This option might prove problematic practically because of the doctrines of acte clair and acte éclairé, which preclude national courts from asking for preliminary rulings if the norms in question are sufficiently clear or have been already interpreted by the CJEU. ${ }^{80}$ National courts and tribunals could refrain from asking the CJEU if one of these doctrines applied in the given case, but would be interested in obtaining the ECtHR's interpretation of Convention norms.

The solution might be to modify both doctrines by lex specialis clause in the AA which would stipulate that whenever national courts and tribunals are willing to request the ECtHR for an advisory opinion, they should also request a preliminary ruling from the CJEU. Regardless of whether the CJEU would deliver its ruling or would refuse to answer the legal question on the ground of the acte clair or acte éclairé doctrines, requesting a preliminary ruling, and obtaining the final decision of the CJEU would constitute a necessary condition for

\footnotetext{
${ }^{79}$ See Fabrice Picod, La Cour de justice a dit non à l'adhésion de l'Union européenne à la Convention EDH, 6-9 LA SEMAINE JURIDIQUE - EDITION GENERALE 233 (2015).

${ }^{80}$ See Frédéric Krenc, La comparaison des systèmes de procédure communautaire avec ceux de la Convention européenne des droits de l'homme, in QUELLE JUSTICE POUR L'EUROPE? LA CHARTE EUROPEENNE DES DROITS FONDAMENTAUX ET LA CONVENTION POUR L'AVENIR DE L'EUROPE 82-83 (2004) (explaining the doctrine of acte clair/acte éclairé in the context of the ECHR).
} 
requesting an advisory opinion. Such a solution might contribute to harmonious development of case law of both European courts because their stances on the same question could be confronted without explicit legal conflict. Advisory opinions will not be binding and preliminary rulings would be, so national courts will have to follow the latter, which would otherwise occur in an individual case brought to the ECtHR. Both European courts would learn each other's approach and could compromise before the legal clash effectively happens. This option constitutes a useful safety valve and turns the unwanted interaction between Protocol No. 16 and EU law into a fruitful source of cooperation between the two courts.

It entails at least three practical problems. The first is the need to guarantee that national courts and tribunals effectively follow the CJEU's answer and not the advisory opinion. Although it seems obvious that Article 267 TFEU is binding and advisory opinions will not have this status, in case of conflicting interpretations of the CJEU and the ECtHR, national courts might be tempted to find "a medium path"-specifically, the interpretation of Convention rights which conforms to views of both European courts. For this reason, reaffirming the binding force of Article 267 TFEU in the case of a national court requesting for an advisory opinion proves sensible.

The second problem potentially poses more difficult challenges. If the AA has a clause stipulating a condition of requesting an advisory opinion, which would be dependent on a previous request for a preliminary ruling, the effective modification of doctrines of acte clair and acte éclairé might be viewed as amending the Treaties by the AA through a procedure which is not envisioned by the Treaties. Although TFEU does not explicitly proscribe either doctrine, the CJEU derived them from the Treaties. This difficulty can hardly be solved, but the CJEU could simply turn a blind eye on such an AA clause if it is meant to strengthen the effectiveness of EU law.

The third problem is the recurring difficulty of safeguarding the effective observation of such a clause. The only feasible solution consists of linking the right to request an advisory opinion from the ECtHR with a special criterion of admissibility-namely the previous request for a preliminary ruling by the CJEU. Such a criterion would have to be assessed by the ECtHR, which - as it can be argued-would thus be granted the right to interpret EU law. In this case the scope of assessment is particularly confined to the existence of any previous CJEU ruling, so it might be taken as a premise of factual, not legal character. Therefore, it should not be rejected on the ground of protecting autonomy of EU law.

This point of Opinion 2/13 doesn't pose intractable problems; on the contrary, a few solutions occur. The difficulty lies, however, in choosing the option which will not undermine the sense of adopting Protocol No. 16 and simultaneously will be acceptable to the CJEU. Given its far-reaching consequences, excluding the application of the Protocol should be rejected. A formal coordination clause or a mechanism declaring the request for a 
preliminary ruling as a condition for requesting an advisory opinion appears a better compromise between the two demands.

\section{Exclusion of Inter-Party Applications}

The fourth point of Opinion $2 / 13^{81}$ concerns the need to exclude the inter-party applications stipulated by Article 33 ECHR. The justification of this demand is based on Article 344 TFEU. This article precludes Member States from submitting disputes concerning the interpretation or application of the Treaties to any other methods of settlement other than those provided therein; moreover, submitting such applications would conflict with the general duty of loyalty pursuant to Article 4, paragraph 3 of the TFEU.

\section{Conclusions of the Fourth Point}

The need to exclude these applications has been familiar to the doctrine for a long time. ${ }^{82}$ It couldn't have been a novelty to negotiators, especially because Article 3 of Protocol No. 8 of the EU explicitly referred to the necessity of safeguarding Article 344 of the TFEU. This could not be construed as alluding to the potential conflict between inter-party applications and the jurisdiction of the CJEU. Thus, the apparent omission in the DAA to exclude these applications was not the result of any forgetfulness, but a deliberate choice on the part of negotiators who deemed it more appropriate to leave the decision on the admissibility of such applications to the discretion of the EU. ${ }^{83}$

Nevertheless, the CJEU found that the mere possibility of filing inter-party applications allowed by the ECHR might violate Article 344 of the TFEU, notwithstanding safeguards provided by EU law. This conclusion was received with considerable surprise. It expanded

\footnotetext{
${ }^{81}$ Adhésion, Case 2/13 at para. 201-14.

82 See Francesco Capotorti, À propos de l'adhésion éventuelle des Communautés à la Convention européenne des droits de l'homme, in DAS EUROPA DER ZWEITEN GENERATION. GEDÄCHTNISSCHRIFT FüR CHRISTOPH SASSE 720 (Roland Bieber \& Dietmar Nickel eds., 1981, vol. II); Gérard Cohen-Jonathan, La problématique de l'adhésion des communautés européennes à la Convention européenne des droits de l'homme, in ÉTUDES DE DROIT DES COMMUNAUTÉS EUROPÉENNES. MÉLANGeS OfFERTS À PIERRE-HENRI TEITGEN 106 (1984); Hans-Christian Krüger \& Jörg Polakiewicz, Propositions pour la création d'un système cohérent de protection des droits de l'homme en Europe. La Convention EDH et la Charte des droits fondamentaux de I'UE, 13 REV. UNIV. DR. H. 14 (2001); Florence Benoît-Rohmer, L'adhésion de I'Union à la CEDH, 12 ReV. UnIV. DR. H. 61 (2000); Christos L. Rozakis, The Future of the Protection of Human Rights in Europe: Accession of the European Union to the European Convention on Human Rights, in DER BEITRITT DER EUROPÄISCHEN UNION ZUR EMRK 299; Olivier de Schutter, L'adhésion de l'Union européenne à la CEDH: feuille de route de la négociation, 83 REV. TRIM. DR. H. 562 (2010); Laura Pavlidis, EU UND EMRK. RECHTSFRAGEN DES BEITRITTS 51 (2012); Huber, supra note 18, at 147; Obwexer, supra note 29, at 121.

${ }^{83}$ See Lock, supra note 7, at 254.
} 
the MOX Plant doctrine ${ }^{84}$ hardly consistent with the fact that the EU is already a party to some international agreements which allow for potential infringements of Article 344 of the TFEU by Member States. ${ }^{85}$ These doubts are almost irrelevant for the problem's solution pointed out by the Court. In fact, this point of Opinion 2/13 poses little practical difficulty in comparison with others.

\section{Solutions to the Fourth Point}

Among more original proposals, one deserves particular attention: Excluding the inter-party applications through unilateral declarations of Member States and also of the EU. Its unquestionable advantage in this case is that the general regime of inter-party applications - which, despite their limited practical significance for European human rights protection, constitute a traditional method of safeguarding the observance of the human rights treaty-will not be confined. The exclusion of inter-party applications between the EU and its Member States might be much more acceptable if their general legal basis remains intact. In this regard, unilateral declarations could be perceived not as its modification which dismantles the control system of the Convention - although, it might be argued, they will modify it de facto-but as individual decisions by Member States which attach high priority to their cooperation. This option might thus stand a better chance of acceptance from other parties to the ECHR.

Daniel Halberstam proposed another potential advantage of this solution suggesting that in the case of severe human rights protection deficiencies within the EU, the ECtHR could disregard the declarations and admit an inter-party application between Member States or between Member States and the EU in the scope of EU law. ${ }^{86}$ Abstracting from the slim chances of the ECtHR approach and the impracticality of this scenario, Halberstam's argumentation is counter-effective. If the solution based on declarations was adopted on this ground, the CJEU would have to reject it because it does not guarantee the realization of its demands. Consequently, such possibility is more a drawback than an unambiguous advantage, although it shouldn't cast doubt on this solution.

In turn, the arguments against this option repeat for all intents and purposes the ones previously formulated against relying on unilateral declarations. Even if their legal effect is like the one of an AA clause, they do not provide the level of legal certainty and of coherence for the ECHR regime that such a clause does. The wording of Opinion 2/13 also seems more

\footnotetext{
${ }^{84}$ Case C-459/03, Comm'n v. Ireland, 2006 E.C.R. I-04635, para. 80-135; see also Nikolaos Lavranos, Jurisdictional Competition. Selected CASES IN INTERNATIONAL AND EUROPEAN LAW 24-30 (2009); Johansen, supra note 5, at 174-75.

${ }^{85}$ See Halberstam, supra note 5, at 118; Johansen, supra note 5, at 176-77.

${ }^{86}$ See Halberstam, supra note 5, at 120.
} 
favorable for the clause option because the Court demands "the express exclusion of the ECtHR's jurisdiction under Article 33 of the ECHR." ${ }^{87}$

The only problem with the latter solution is also familiar: It is unclear whether the exclusion of inter-party applications might really be confined to the scope EU law's application. Although the CJEU explicitly noted that it should concern "the application of the ECHR within the scope ratione materiae of EU law," ${ }^{88}$ repeating this formula in the future AA clause might effectively grant the ECtHR the right to assess admissibility of inter-state applications because of their pertinence to EU law. ${ }^{89}$ Given the scarcity of such applications in the Strasbourg control system's history, the problem seems marginal. Nonetheless, as it already occurred between EU law and other systems of law, an unlikely situation may surprise and bewilder scholars. As with limitations to the scope of application of EU law, the total exclusion of inter-state applications in relations between EU parties to the ECHR might be a safer option, although it would significantly limit the practical role of Article 33 of the ECHR.

Which option should be adopted? In this case-contrary to other instances of the limiting clause problem-it seems reasonable to prefer the most effective inter-state applications. Because their functioning in the current shape directly affects the protection of individuals, providing excessive safeguards for the autonomy of EU law cannot be deemed a prevailing goal. Nonetheless, the wording of the Opinion leaves little margin of appreciation, although it only restricts the exclusion to the scope of EU law. Overall, the clause option seems safer. Fortunately, the wording of Opinion 2/13 allows for transmitting the Court's formula almost verbatim to the $A A$, thus disregarding the problem of the ECHR's interpreting the EU lawrelated admissibility criterion.

\section{The Co-Respondent Mechanism and Its Discontents}

The next three points of Opinion $2 / 13^{90}$ concern the co-respondent mechanism. ${ }^{91}$ As they are all linked by the reference to the same legal institution, it is sensible to analyze them altogether.

\footnotetext{
${ }^{87}$ Adhésion, Case 2/13 at para. 213.

${ }^{88}$ See id., at para. 213.

${ }^{89}$ See Lock, supra note 7 , at 255-56.

${ }^{90}$ Adhésion, Case 2/13 at para. 215-35.

${ }^{91}$ Hereinafter as CRM. See Gragl, supra note 29, at 148-49; Johan Callewaert, THE ACCESSION OF THE EUROPEAN UNION TO THE EUROPEAN CONVENTION ON HUMAN RIGHTS 66 (2014); José Manuel Cortés Martìn, Sur l'adhésion à la CEDH et la sauvegarde de l'autonomie de l'ordre juridique de l'Union dans l'identification du défendeur pertinent: le mécanisme du codéfendeur, 4 REV. DR. U.E. 640 (2011); Xavier Groussot, Tobias Lock, Laurent Pech, EU Accession to the European Convention on Human Rights: a Legal Assessment of the Draft Accession Agreement of 14th October 2011, 218 EUR. IsS. 4 (2011) (On the co-respondent mechanism).
} 


\section{The Three Points and the Current Model of the Co-Respondent Mechanism (CRM)}

The objections of the Court in this area are limited and could have been foreseen during drafting. Two of them concern the unjustified discretion granted to the ECtHR. The DAA was supposed to decide on: (1) the request of a Member State or of the EU to join the proceedings against a party to the ECHR, if the conditions of launching the CRM are met; and (2) the exclusive responsibility of either the respondent or the co-respondent in the previously triggered CRM, if sufficient reasons given by these parties-and to a lesser extent the applicant-support such a ruling.

Both objections seem to concern only particular co-respondent mechanism regulations, but, in fact, are related to some fundamental presuppositions concerning this institution. Because the critique of the envisioned CRM exceeds the scope of this Article, it will be only briefly mentioned that regulations questioned by the CJEU result from a piecemeal and conservative vision of the CRM that the EU adopted, such as excluding in advance the possibility of obligatory coopting of the co-respondent and not providing more detailed rules governing the regime of joint responsibility. The purely technical solution of the abovementioned problem does not pose much difficulty, but the true challenge would be to shape the CRM not only in a coherent, but also efficacious manner.

The third objection ${ }^{92}$ regards a loophole of marginally practical importance; ${ }^{93}$ namely a situation in which-after the co-respondent mechanism is launched-joint responsibility could be declared even though a Member State, being a respondent or a co-respondent, makes a reservation concerning an ECHR right at issue. Although the objection of the CJEU is pertinent, it omits a much bigger problem-namely the relation between the institution of joint responsibility and future rules of attribution adopted by the ECtHR. In this area, the AA will probably pave the way for the development of international law of shared responsibility.

The brief formulation of Article 3, paragraph 6 of the DAA, which only stipulates that joint responsibility might be declared because of the co-respondent mechanism, cannot regulate the future practice of the ECtHR. The Strasbourg Court will inevitably have to enter some uncharted territories, deciding whether declaring joint responsibility ${ }^{94}$ demands, as its prerequisite, previous attribution of conduct to both the respondent and the co-respondent.

\footnotetext{
92 For reasons of coherence, the order of this presentation diverges from the exact order of the Court's objections as presented in the body of Opinion 2/13. The objection presented here as the third one is the second in the CJEU'S arrangement.

93 See Lock, supra note 7, at 249-50.

94 See generally PRINCIPLES Of SHAREd ReSPONSIBILITY In INTERNATIONAL LAW. AN APPRAISAL OF THE STATE OF THE ART (André Nollkaemper \& Ilias Plakokefalos eds., 2014) (on shared and joint responsibility in international law).
} 
If so, whether their conduct violates the international obligations imposed by the ECHR on both. In other words, the ECtHR will have to assess whether joint responsibility, as established by the future AA, is an actual sum of particular attributions of responsibilityeven if they are not explicitly revealed in the ruling-or whether it creates a kind of "corporate veil" over responsibility of both the respondent and the co-respondent, in which case one of them could be declared responsible for an act which is not solely attributable to it or which didn't infringe, in itself, the ECHR. The latter option seems better suited to the goals of the co-respondent mechanism, as it excludes the possibility of separate attribution of responsibility. The former precludes by itself the situation to which the CJEU referred in its third objection regarding the CRM, because joint responsibility cannot be declared if separate responsibility isn't preliminarily attributable to each of the respondents. ${ }^{95}$

As these problems exceed the scope of this Article, they will be mentioned here only briefly. Nevertheless, it should be noted that the CJEU revealed only a beginning, which will have to be first reconsidered by the negotiators and then by the ECtHR. Consequently, the challenge posed by this point of the Opinion is not how to find solutions for each particular objection raised by the Luxembourg Court, which is relatively tractable, but whether the EU should settle for these patchy improvements instead of designing a more ambitious CRM.

Setting this dilemma aside, let us assume that the modest approach is adopted and each of the Court's objections is treated individually with a small, but satisfactory solution.

\subsection{Solutions to the First Objection}

There are at least two solutions to the first objection. If the decision of the ECtHR is purely formal-as argued before the CJEU in the proceedings ${ }^{96}$-and the need for the existence of this decision is deemed significant-such as to maintain the necessary order of proceedings - the demands of the CJEU could be met through restating the relevant clause of the future AA so that it would clearly state this formal character. For instance, replacing "decision" and "deciding" with "acknowledging" a potential party's request would solve this. An extra clause might be added which would stipulate that such a request obliges the ECtHR to formally acknowledge the party's co-respondent status.

The second solution involves relinquishing the ECtHR's decision. The party would acquire the co-respondent status simply by its own request. This option proves safer in the light of the CJEU's demands, although prima facie it might seem more confusing before the Strasbourg Court. Nevertheless, the third-party intervention-stipulated by Article 36, paragraph 1 of

\footnotetext{
${ }^{95}$ Parenthetically, it should be mentioned that the problem the Court referred to would arise also in situations in which the international obligations of the respondent and the co-respondent differ not because of a reservation, but because different Protocols to which they are parties.

${ }^{96}$ See Lock, supra note 5; Lock, supra note 7, at 247.
} 
the ECHR-doesn't require that the ECtHR grant this status to the requesting party through a formal decision, despite that the third-party intervention doesn't pose real organizational problems. In any case, more detailed provisions might be laid down in the Rules of the Court.

Overall, the lack of the ECtHR's formal decision doesn't infringe the rights of any of the parties, including the applicant. Because a party to the Convention expresses the will to become a co-respondent, it cannot be harmed by its own request, according to the maxim volenti non fit iniuria. Dogmatically, the more problematic aspect is the fact that the criterion of admissibility of the CRM-currently stated in Article 3, paragraphs 2 and 3 of the DAAwill lose its sense in the case of parties' requests. There will be no external body entitled to assess its conformity with the filed request. Although it might provide guidance to the parties on which situations should trigger the CRM, it will be redundant because the parties will assess the need of setting off the CRM according to their own interest. Primarily, it will be the EU protecting the autonomy of its law. Consequently, if the will of the parties is to be decisive, the condition of admissibility might as well be either expressly confined to cases in which the ECtHR considers inviting a party, or is completely removed from the DAA. It isn't particularly coherent to exclude the possibility of the ECtHR's assessment of EU law in case of parties' requests and allow it in case of invitations.

\subsection{Solutions to the Second Objection}

When it comes to the second objection concerning the CRM, the demands of the CJEU seem unequivocal. The Court spared the negotiators, who could be tempted to modify the challenged provision to preserve the possibility of apportioning responsibility by the ECtHR. The CJEU even excluded the option of explicitly binding the ECtHR by a respondent's joint request and the co-respondent. The apportionment of responsibility must be reserved for the Luxembourg Court. If taken for granted, the simplest solution would be to drop all references to the apportionment of responsibility in the future AA. The apportionment could be effectively carried out between the EU and a Member State, but beyond the scope of intervention of the ECtHR. In this case, triggering the CRM would entail the necessity of declaring joint responsibility-even in proceedings where the ECtHR finds only one of the respondents responsible-which could be apportioned according to internal EU rules. ${ }^{97}$

\footnotetext{
97 See Gragl, supra note 29, at 168-70; Tobias Lock, EU Accession to the ECHR: Implications for Judicial Review in Strasbourg, 35 EUR. L. REV. 787 (2010); Schutter, supra note 82, at 560; Julie Vondung, DIE ARCHITEKTUR DES EUROPÄISCHEN GRUNDRECHTSCHUTZES NACH DEM BEITRITT DER EU ZUR EMRK 244 (2012); Pavlidis, supra note 82, at 122; Michael Potacs, Der Beitritt der Europäischen Gemeinschaft zur Europäischen Menschenrechtskonvention aus gemeinschaftsrechtlicher Sicht, in ÖSTERREICH UND DAS RECHT DER EUROPÄISCHEN UNION 86-87 (Waldemar Hummer \& Michael Schweitzer eds., 1996); Susanne Stock, DER BEITRITT DER EUROPÄISCHEN UNION ZUR EUROPÄISCHEN MENSCHENRECHTSKONVENTION ALS GEMISCHTES ABKOMMEN? 323 (2010) (On the apportionment of responsibility between the respondent and the co-respondent).
} 
It doesn't mean, however, that this would be the only option. Responsibility might be apportioned within the framework of an internal EU procedure before the ECtHR issues its final ruling. Such possibilities were considered before the CRM idea gained ground-with the option of some form of preliminary ruling of the CJEU on request from the ECtHR as the principal solution. Nevertheless, the CRM won out as the simplest solution, at least apparently. Mixing it with an additionally troublesome institution of preliminary rulings would thus not be reasonable.

Setting aside this possibility, it must be noted that the CJEU itself seems to suggest yet another option, consisting in preserving the possibility of the ECtHR's declaring individual responsibility, but on the respondents' univocal requests which were previously subjected to the CJEU's approval. If the CJEU approves these requests, there seems to be no obstacle to declaring individual responsibility, if only a relevant provision safeguards that the ECtHR be bound by them. In this case, the CRM would not be a one-way street because the ECtHR could terminate it in close cooperation with the CJEU. Even if this option appears somewhat burdensome, it might be a valuable contribution to the CRM's efficacy because the parties might be more eager to request the co-respondent status if they know they could relinquish it during the proceedings. Moreover, the complexity of this solution is not necessarily disadvantageous: The necessity of approval of the CJEU would encourage the parties to make responsible choices to terminate the CRM. This option seems to reconcile the demands of the CJEU with the requirements of flexibility of the CRM.

Carrying this out necessitates amending the final sentence of Article 3(7) of the DAA in the following manner:

Unless the respondent and the co-respondent conclude an agreement on the apportionment of responsibility, which has been approved by the Court of Justice of the European Union in which they jointly request for deciding that only one of them be held responsible, the request of the respondent and the co-respondent binds the Court.

The wording of this clause shows that the solution in question can trigger resistance from non-EU parties to the Convention and from the ECtHR itself because the co-respondent and the respondent could effectively modify the ECtHR's rulings. Although one of them would remain responsible, the other might elude its responsibility. Moreover, to function effectively, the clause should be supplemented by a provision stipulating that the ECtHR stall the proceedings to let the CJEU review the agreement. ${ }^{98}$ Therefore, this option, despite its advantages for the CRM, might prove difficult to negotiate. If non-EU parties to the

${ }^{98}$ For example, modeled after current Article 3(6) of the DAA. 
Convention object, it will have to be dropped and the CRM escape clause would have to be removed from the $A A$.

Parenthetically, the CJEU completely disregarded the applicant's position. Although Tobias Lock proposed upholding or even increasing the role of the applicant's acceptance in terminating the $\mathrm{CRM},{ }^{99}$ the CJEU emphasizes that it is the only subject empowered to ultimately decide on the apportionment of responsibility between the EU and its Member States. Therefore, the applicant might, at most, express her views in the proceedings before the CJEU.

\subsection{Solutions to the Third Objection}

Finally, the third objection of the CJEU might be solved easily with a future AA provision stating that joint responsibility cannot be declared if it arises from an infringement of a Convention-imposed obligation which doesn't bind both the respondent and the corespondent.

Such wording avoids the situation referred to by the CJEU, but also eliminates the loophole which exists in the current Article 3(3) of the DAA. According to this provision, the CRM might be set off by granting the Member States the status of co-respondents if the application is directed against the EU and the alleged violation calls into question the compatibility of primary EU law with the rights defined in the ECHR or in the Protocols, which the EU acceded. Taken literally, this article doesn't preclude Member States which didn't ratify a certain Protocol-to which the EU acceded - to join the proceedings. In this case, joint responsibility declared in the final ruling could concern these Member States. Although if it weren't for the CRM, the conditions of attributing responsibility to them wouldn't be met. Consequently, if Article 2 of Protocol No. 8 to the Treaty of Lisbon is not to be infringed, ${ }^{100}$ the future clause of the AA should exclude in a more general manner the possibility of the ECtHR's declaring joint responsibility in case of divergent obligations of the EU and its Member States.

While this problem seems not to apply to the version of the co-respondent mechanism from Article 3(2) of the DAA, in which the EU is the co-respondent, it should be noted that its provision might also require more precise wording. Although the EU cannot join the proceedings if the allegation concerns a nonbinding obligation, it is unclear how the institution of joint responsibility will function in situations where the act in question

\footnotetext{
${ }^{99}$ See Lock, supra note 7, at 248-49.

100 Protocol Relating to Article 6(2) of the Treaty on European Union on the Accession of the Union to the European Convention on the Protection of Human Rights and Fundamental Freedoms to the Treaty of Lisbon Amending the Treaty on European Union and the Treaty Establishing the European Community (Dec. 13, 2007), 2007 O.J. (C 306) 1.
} 
allegedly violates multiple rights from the Convention and its Protocols. Theoretically, the wording of Article 3(2) of the DAA allows a separate adjudication on the joint responsibility concerning the infringement of one right-binding both the Member State and the EU-and individual responsibility for the infringement of another-binding only the Member State. This is because the CRM is triggered in relation to particular allegations, not acts. This possibility corresponds with the fact that whenever a case will concern a right from the Protocol which was ratified by the Member State but not by the EU, the status quo of the regime of responsibility will be upheld as if the accession did not happen, which is a wellknown price to be paid for the option of "protocols of the lowest common denominator."

In light of Article 3(2) of the DAA, the price might be actually higher because there might be situations in which the ECtHR will have to declare-in the same ruling-both joint responsibility in respect to one allegation and individual responsibility in respect to another. Both allegations will differ not in the attribution of act, but in the divergent legal obligations of the parties. In this situation, the attribution of act in respect to individual responsibility will effectively reveal the attribution in respect to joint responsibility, even if the latter is hidden by the "corporate veil."

Therefore, the CJEU's critique of the DAA could be used as a starting point for reworking this aspect of the CRM, so that the possibility of parallel attribution of joint and individual responsibility would be regulated, not just allowed or excluded.

\section{The Future of the Co-Respondent Mechanism}

Overall, the three objections of the Court concerning the CRM are relatively easy to overcome. Solutions are available without much disagreement from other parties to the ECtHR. Yet a challenge in this area is not posed by particular solutions, but in the necessity of reconsidering whether the CRM is to remain regulated in part-like the DAA-or, perhaps, more comprehensively, predominantly in respect to joining the proceedings and rules of attribution of joint responsibility. The CRM has been drafted as a fully facultative mechanism because the autonomy of EU law is supposed to demand such a solution. Nevertheless, this argument is double-edged. Without all Member States joining the proceedings obligatorily where the conformity of primary EU law with the ECHR is called into question, the CRM will prove ineffective and the autonomy of EU law might be under real threat. As these considerations exceed the scope of this Article, it is necessary only to mention that particular solutions in the CRM area-although fully possible from the technical point of view-won't protect EU law sufficiently. 


\section{Prior involvement of the Court of Justice}

The eighth and the ninth point ${ }^{101}$ of the CJEU's critique concerns the so-called prior involvement procedure, which is aimed at providing the EU-or, more specifically, the CJEU-the opportunity to assess the validity of an act whose concordance with the Convention is put into question by the applicant's allegation. As in the case of the CRM, the unity of the institution calls for a joint analysis of these two points.

\section{Conclusions of the Eighth Point and Possible Solutions}

The first of these two points-undoubtedly marked by a logical incoherence-refers to two flaws of the DAA: (1) The lack of indication to which an institution is entitled to set off the prior involvement procedure (PIP), and (2) not determining means of informing the EU about the possible necessity of initiating the PIP. The relation between these two flaws is not obvious. Whereas the former seems to be the real core of the problem, it is the latter that opens-with the word "consequently" - the final part of the argumentation and misleadingly gives the impression that the lack of mechanisms of information is not only the consequence of the former, but also the major obstacle to be removed. Even though both flaws are contained within one objection of the Court, they demand different solutions with separate analyses.

\subsection{The First Flaw: Institution Responsible for Triggering the PIP}

As to the first flaw, the DAA doesn't determine the institution responsible for launching the PIP, but only formulates a condition for setting off the procedure and provides sufficient time for the CJEU without even referring precisely to the subject to which it is meant to afford this time. Such brief formulation was likely deliberate because the negotiators intended to grant the broadest possible autonomy to the EU. ${ }^{102}$ Nonetheless, they omitted the fact that the elusive wording of Article 3(6) of the DAA allows the ECtHR-at least theoretically-to take control of the procedure by assessing individually whether the condition of the PIP is met and, on this ground, granting or refusing additional time for the

\footnotetext{
${ }^{101}$ Adhésion, Opinion 2/13 at para. 236-248.

102 The explanatory report to the DAA implicitly refers to the priority given to internal EU procedures:

Even though this situation is expected to arise rarely, it was considered desirable that an internal EU procedure be put in place to ensure that the CJEU has the opportunity to assess the compatibility with the rights at issue defined in the Convention or in the protocols to which the European Union has acceded of the provision of EU law which has triggered the participation of the EU as a co-respondent. (emphasis added)
}

Draft explanatory report, supra note 2, para. 66. 
CJEU, even against the EU's stance. Apart from the odds of such a hostile move, the Court's objection is pertinent because the omissions in the formulation of Article 3, paragraph 6, of the DAA went too far. Even if internal EU rules supplement the Agreement, they cannot intervene into the ECHR procedures to the point of determining the role of the ECtHR within the PIP. Therefore, the CJEU's remark calls for safeguarding the position of EU law as much as Convention law.

Practically concerned, no insurmountable obstacles appear in this area. The solution entails redrawing the line separating rules of EU law from rules of Convention law so that the autonomy of both is secure. Three principal issues might demand more precise regulation: (1) Determining the institution empowered to decide on triggering the PIP on the basis of the condition laid down in the AA, (2) naming the institution responsible for affording the sufficient time for the CJEU-even though the ECHR is the only obvious candidate, the CJEU's demands require clear separation of roles in the PIP-and (3) guaranteeing that the ECtHR is bound by the decision taken by the institution referred to in (1). The division between EU law and Convention law seems to best coincide with the following solution: (2) and (3) are decided by explicit provisions in the $A A$, as directly related to the procedure before the ECHR, while the determination of the institution in (1) is left to an autonomous decision of the EU. Nevertheless, it needs to be stipulated in the AA that it is an EU institution that takes a binding decision of triggering the PIP, even though the name of this institution might not, or should not, appear explicitly in the AA.

Overall, the conditions are best met by the following clause, replacing the current wording of the first sentence of Article 3, paragraph 6, of the DAA:

In proceedings to which the European Union is a corespondent, if the European Union declares that the Court of Justice of the European Union has not yet assessed the compatibility with the rights at issue defined in the Convention or in the protocols to which the European Union has acceded of the provision of European Union law as under paragraph 2 of this article, the Court shall afford sufficient time for the Court of Justice of the European Union to make such an assessment, and thereafter for the parties to make observations to the Court.

This formulation provides a compromise between explicitly naming the EU institution responsible for assessing the criterion for PIP admissibility and ensuring that the EU makes a binding decision in this respect. Although the wording seems unequivocal, an additional clause stating that the ECtHR is bound by the EU decision can be added if necessary. Parenthetically, the realization of the CJEU's demands makes the criterion of admissibility 
effectively obsolete just as in the case of the CRM because the EU would be both the subject demanding the PIP and the body assessing grounds for it.

\subsection{The Second Flaw: Channel of Information}

The second flaw referred to by the CJEU cannot be easily linked to an evident solution. The Court demands that the EU be "fully and systematically" ${ }^{103}$ informed about all cases pending before the ECtHR. This means that the EU institution responsible for assessing the need for launching the PIP could take a well-grounded decision. This requirement is hardly understandable given that the PIP might be triggered only when the CRM has been set off, in which case the EU-already a co-respondent to the proceedings-would have sufficient information to decide on the PIP. ${ }^{104}$ In this sense, it would be much more sensible to provide for a special procedure of informing the EU on cases that potentially involve the need for launching the CRM. Nevertheless, the CJEU explicitly refers to a procedure of informing in "all cases" pending before the ECtHR. This statement might be interpreted in two ways: As an implicit call for dissociating the PIP from the $\mathrm{CRM}^{105}$ or a general demand to provide the EU with sufficient information on EU-related cases before the ECtHR. As no arguments for the former were given by the CJEU, it must be assumed that the Court simply intended to establish a privileged channel of communication.

The fact that the CJEU contained this requirement in the section concerning the PIP leaves doubts as to whether the channel of information should apply precisely to all cases pending before the ECtHR or whether it should be limited. For example, this may be in cases when the CRM might be set off or has been already set off, or in cases where there is a potential link with EU law. The unequivocal wording of this point-read in the whole context-makes both alternatives plausible. It still must be considered that the Opinion not only poses theoretical problems for academics, but practical problems too. In this light, more abstract legal opinions must succumb to accepting options which are safer for the negotiators. Given that the autonomy of EU law is a preferred value of the CJEU, all limitations of the information mechanism allowing the ECtHR to assess the relevance of a given case for EU law should be avoided. For this reason, it would be simpler and safer to create a special information mechanism concerning all cases before the ECHR.

\footnotetext{
${ }^{103}$ Adhésion, Case 2/13 at para. 241.

${ }^{104}$ See Lock, supra note 7, at 252.

${ }^{105}$ Establishing the PIP without the necessary link with the CRM wouldn't be senseless by any means. There might be cases in which applications were filed against the EU alone where the CJEU did not assess previously the compatibility with the ECHR of a norm of EU law in question and no remedy to the CJEU must have been exhausted according to Article 35 paragraph $1 \mathrm{ECHR}$-namely if no Treaty remedies were available to the applicant in a given case, either ratione materiae or ratione temporis. In these situations, the PIP would be useful even though the CRM cannot be launched.
} 
Even if this path is adopted, two problems remain. First, what should the exact content of this information be? Second, how should it be determined in the future AA? The wording of the Opinion is hardly helpful in this regard. By demanding "systematic" information, the CJEU seems to suggest that the ECtHR should prepare some specifically targeted reports on all cases, already selecting those which might be relevant in the context of EU law. "Full" information, however, might mean nothing less than sending all materials on all cases, without pre-selection. The wording "fully and systematically informed" has at least some potential of displaying inherent contradiction.

"Full" information might be provided easily. According to Rule 33 of the ECtHR's Rules of Court, ${ }^{106}$ all documents deposited with the Registry by parties are already, with few exceptions, accessible to the public. The EU could simply have a permanent resident in the Registry in charge of examining these documents. Alternatively, the ECtHR could provide the direct or electronic access to them for the EU. The "systematic" information could require that the Registry of the ECtHR prepares at various stages of proceedings concise reports for the EU with attention to the possibility of setting off the PIP or the CRM, although it shouldn't make suggestions infringing on the autonomy of EU institutions. From the point of view of Strasbourg, it will create an additional administrative burden. Consequently, the option closer to the requirement of "fullness" should be given priority in the interest of both the ECHR and the EU.

As to the level of regulation, the AA should not be overburdened with too much detail. Moreover, vague wording risks the CJEU mitigating its previous demands and not disqualifying the future AA. The following general clause in the AA could be the starting point of considerations: "The Court will fully and systematically inform the EU on all pending cases." It might be further developed in an appendix to the AA or in the Rules of the Court. Some limitations of the clause might be added restricting its application to cases in which EU law is relevant.

\section{The Ninth Point: Interpretation v. Validity}

\subsection{Conclusions of the Ninth Point}

The ninth critical point of the Opinion-and the second one which concerns the PIP-calls into question the scope of duties of the CJEU within the PIP.

Article 3(6) of the DAA determines the Court's task as "making assessment" of "the compatibility with the rights at issue defined in the Convention or in the protocols to which the European Union has acceded of the provision of European Union law." Although this

106 See European Court of Human Rights, RulES OF COURT 33 (Nov. 16, 2016), http://www.echr.coe.int/Documents/Rules_Court_ENG.pdf. 
provision doesn't specify the exact scope of such assessments, the draft explanatory report focuses on the basic division of the tasks of the CJEU as stipulated in 264 TFEU-namely, adjudicating the validity of a provision of secondary law and on the interpretation of a provision of primary law. ${ }^{107}$ Therefore, as the CJEU rightly noted, the PIP could not be triggered if the Court were to rule on a question interpreting a provision of secondary law and not on its validity. The CJEU perceives this restriction as a loophole which might allow the ECtHR - when confronted with the question of conformity of a provision of EU law with the Convention-to choose autonomously from plausible interpretative options concerning this provision. Such a liberty of the Strasbourg Court would, according to the CJEU, breach its exclusivity of interpreting EU law.

Apart from the fact that the Court might have pointed out this risk earlier, when it signaled the need to establish the PIP ${ }^{108}$-thereby sparing the time and energy of the negotiators-the CJEU's argumentation in this regard is hardly convincing. First, the Court expressly assumes that the task of the ECtHR will consist of assessing the conformity of a provision of EU law with the Convention, which doesn't properly reflect the ECHR's scope of review. The ECtHR was established to adjudicate violations of the Convention, not on the mere conformity of national laws with the ECHR. In this case, the position of EU law will correspond to the position of norms enacted by other parties to the Convention. ${ }^{109}$

107 See Draft explanatory report, supra note 2, para. 66.

\begin{abstract}
Even though this situation is expected to arise rarely, it was considered desirable that an internal EU procedure be put in place to ensure that the CJEU has the opportunity to assess the compatibility with the rights at issue defined in the Convention or in the protocols to which the European Union has acceded of the provision of EU law which has triggered the participation of the EU as a co-respondent. Assessing the compatibility with the Convention shall mean to rule on the validity of a legal provision contained in acts of the EU institutions, bodies, offices, or agencies, or on the interpretation of a provision of the TEU, the TFEU, or of any other provision having the same legal value pursuant to those instruments.
\end{abstract}

${ }^{108} \mathrm{Cf}$. The Court of Justice of the European Union, DISCUSSION DOCUMENT OF THE COURT OF JUSTICE OF THE EUROPEAN UNION ON CERTAIN ASPECTS OF THE ACCESSION OF THE EUROPEAN UNION TO THE EUROPEAN CONVENTION FOR THE PROTECTION OF HUMAN RIGHTS AND FUNDAMENTAL FREEDOMS para. 12 (May 5, 2010), http://curia.europa.eu/jcms/upload/docs/application/pdf/2010-05/convention_en.pdf; see also Breuer, supra note 5 , at 345 .

109 In Neulinger \& Shuruk, the ECtHR remarked:

The Court reiterates at the outset that it is primarily for the national authorities, notably the courts, to resolve problems of interpretation of domestic legislation. This also applies where domestic law refers to rules of general international law or to international agreements. The Court's role is confined to ascertaining whether those rules are 
Second, the CJEU turns an exception into a rule. The PIP was conceived as a method of supplementing the restricted jurisdiction of the CJEU over EU legislation, not as a general channel of exchanging views on interpretation between the two courts. The main idea of the PIP was to grant to the CJEU the right to remove the violation before the ECtHR declares it. Nevertheless, the Luxembourg Court demanded the prerogative to determine in advance the interpretation of EU law that the Strasbourg Court will have to adopt, even if the actual practice of the EU was previously divergent from the correct interpretative option selected by the CJEU. In this case, the ECtHR would effectively be prevented from declaring that the provision in question was in fact applied differently.

Third, the demanded amendment might open the way to an improbable, yet possible, scenario where the PIP is triggered in cases when the CJEU would be eager to interpret the Accession Agreement itself, which-against some separate opinions ${ }^{110}$-will belong to the EU's secondary law ${ }^{111}$ and risk severe conflicts with the ECtHR.

Finally, setting aside the fact that the ECtHR usually follows the CJEU's case law with meticulousness, the ECtHR's liberty to interpret a provision of EU law doesn't mean that the interpretative monopoly of the CJEU could be infringed. The ECtHR might simply select a few interpretations and declare that some of them lead to the violation of the Convention, while some of them do not. The CJEU would reserve the question of correctness under EU law, while the ECtHR would concentrate on the actual interpretative practice of EU institutions and Member States in search of possible violations of the Convention.

The practical dimension is also non-negligible. If the PIP is extended to encompass the CJEU's interpreting secondary law, almost every case in which the EU context appears could be a potential cause for triggering the procedure. Given the above-mentioned demands of the Court, it is the EU that should be expected to carry the most burden of this change, since EU institutions, like the EC, will have to scrutinize each case before the ECtHR in search of potential interpretative ambiguities concerning EU law. From the Strasbourg point of view, the duties imposed within the framework of the "full and systematic" information might

applicable and whether their interpretation is compatible with the Convention.

Neulinger \& Shuruk v. Switzerland, 2010-V Eur. Ct. H. R. 100; see also Françoise Tulkens, Pour et vers une organisation harmonieuse, 1 REV. TRIM. DR. EUR. 29 (2011); de Schutter, supra note 82, at 551; Groussot, Lock, Pech, supra note 91 , at 5 .

110 See Benedetto Conforti, L'adhésion de l'Union européenne à la Convention européenne des droits de l'homme, in L'EUROPE DES DROITS FONDAMENTAUX. MELANGES EN hOMMAgE A ALBERT WeitZel 22 (2013); Obwexer, supra note 29, at 144.

${ }^{111}$ Cf. Christian Kohler, Luigi Malferrari, Um letzte und vorletzte Worte: Zum geplantem Zusammenwirken von EGMR und EuGH nach dem Beitritt der EU zur EMRK, 22 EUZW 850 (2011). 
become more laborious. More importantly, a higher number of proceedings before the ECtHR may stall because of the CJEU's time for ruling on the interpretation of a provision of EU law.

\subsection{Solutions to the Ninth Point}

The strength of arguments against extending the PIP to interpretation of secondary law is inversely proportional to the practical difficulty of creating such an option. Merely fulfilling the Court's demands from the previous point of the Opinion de facto realizes the requirements of the current point is astonishing. As the EU is to be the sole subject entitled to request the launch of the PIP and the ECtHR is bound by this request, the premises of the PIP will become practically irrelevant given that the Strasbourg Court will have no means to reject a request which doesn't meet them, especially if they are laid down only in the explanatory report, not in the agreement itself. Nevertheless, because the practical irrelevance of the premises obviously isn't the most elegant and certain option, a more unambiguous solution should be adopted.

It may seem sufficient to amend only the explanatory report, which develops the term "assessment of compatibility" from Article 3(6) of the DAA. Nevertheless, legal certainty and, most importantly, the need of the CJEU's acceptance of the future agreement, demand that this provision be further specified in the AA. Therefore, the easiest option is to enrich the current wording of Article 3(6) of the DAA with the following provision modelled after paragraph 66 of the draft explanatory report because its structure has been already accepted by the parties:

Assessing the compatibility with the Convention shall mean ruling on the validity or interpretation of a legal provision contained in acts of the EU institutions, bodies, offices, or agencies, or on the interpretation of a provision of the TEU, the TFEU, or of any other provision having the same legal value pursuant to those instruments.

In this way, the ninth objection of the CJEU would be realized with minimal difficulty. 


\section{The CJEU'S Jurisdiction over the CFSP}

The last objection of the Court presents the real predicament, ${ }^{112}$ which poses, and already posed, ${ }^{113}$ arguably the biggest challenge for the negotiators. It concerns the intersection of jurisdictions of the CJEU and the ECtHR over cases related to the CFSP.

\section{Conclusions of the Tenth Point}

The problem raised by the Court stems from the fact that its jurisdiction in the area of the CFSP covers only monitoring compliance with Article 40 of the TEU and reviewing the legality of certain decisions under Article 263 (4) of the TFEU. Upon accession, the ECtHR will be entitled to assess compliance with the Convention of all EU acts in this area. The CJEU found that although its jurisdiction over the CFSP isn't sufficiently delimited, even the extensive interpretation supported by the Commission doesn't allow for assuming that jurisdictions of both European courts will overlap. ${ }^{114}$ As a result, after the accession there will be cases when the ECtHR will be the sole judicial body to adjudicate, although only in respect to their conformity with the Convention, which the CJEU perceives as inadmissible, particularly in the light of the Opinion 1/09. ${ }^{115}$

The stance of the CJEU has proved disappointing for some commentators, who pointed out that in some legal systems the ECtHR is perceived as the ultimate guarantor of human rights protection against loopholes of domestic legal remedies. ${ }^{116}$ Moreover, the Court's approach is disheartening inasmuch as it rules out one of pro-accession arguments which was based on the need of extending human rights protection over the CFSP. ${ }^{117}$ The Court effectively renounced external control in this area, thus undermining the goal of accession. Mattias Wandel noted-not without a touch of bitter irony-that for the CJEU "lieber keiner als allein $\operatorname{der}$ EGMR. "118

\footnotetext{
${ }^{112}$ Adhésion, Case 2/13 at para. 249-57.

${ }^{113}$ Lambrecht, supra note 7, at 195.

${ }^{114} \mathrm{Cf}$. Storgaard, supra note 4, at 498.

${ }^{115}$ Case 1/09, Accord sur la création d'un système unifié de règlement des litiges en matière de brevets, 2011 E.C.R. I-01137, para. 78, 80, 89 .

${ }^{116}$ tazowski, Wessel, supra note 5, at 203.

${ }^{117}$ Cf. also CMLR Editorial Comments, supra note 4, at 13.

118 The phrase means "Better no one than only the EctHR." Mattias Wendel, Der EMRK-Beitritt als Unionsrechtsverstoß. Zur völkerrechtlichen Öffnung der EU und ihren Grenzen, 13 NJW 926 (2015).
} 


\section{Solutions to the Tenth Point}

The disillusionment of commentators as to the CJEU's approach created hardships with the practical fulfillment of the Court's requirements. Because the jurisdictions of the two courts don't overlap, there are two classes of solutions: Extending the jurisdiction of the CJEU or restricting the jurisdiction of the ECtHR.

As far as the first is concerned, apart from all obvious complications there is also the other side of the coin: The Court's requirements might be taken as a call for extending its jurisdiction over the CFSP. Given the endless debates on how to cope with the narrow cognition of the CJEU, especially in individual cases, ${ }^{119}$ the Opinion might be seen as a clear appeal for overhauling the system of legal remedies in the EU, which no longer matches the general level of European integration. Naturally, the current l'état d'esprit (state of mind) in Europe doesn't seem conducive to a major reform of the Treaties, but the will to find a proper answer to Brexit might rekindle pro-integrationist initiatives and, quite unexpectedly, bring the issue back to debate.

The other class of solutions concerns restricting the future jurisdiction of the ECtHR over EU acts and omissions in the area of the CFSP. This idea is not new; it appeared already in some scholars' considerations on EU reservations to the ECHR. ${ }^{120}$ Although it cannot be limited by means of reservation-mainly for its inadmissibly general character ${ }^{121}$ and the lack of an EU act which would fulfill the criteria of "law" in the sense of Article 57 ECHR-it might be technically realized through a relevant provision of the AA. Nevertheless, it would constitute an unprecedented restriction of the ECtHR's cognition, which would be manifestly discordant with the idea of increasing the level of human rights protection. For this reason, it is highly likely that the non-EU Parties to the Convention would oppose such a scenario. Interestingly, such a restriction wouldn't be entirely favorable for the EU either as the restriction of the ECtHR's jurisdiction over the CFSP will concern only EU acts or omissions and not those of the Member States undertaken in the application of EU law. In this regard, the Member States will be responsible for their violations of the Convention according to the doctrine codified in Bosphorus, so the accession will not be effective. ${ }^{122}$ Consequently,

\footnotetext{
${ }^{119}$ See Krenc, supra note 80, at 80-92.

120 Martin Kuijer, The Accession of the European Union to the ECHR: A Gift for the ECHR's 60 th Anniversary or an Unwelcome Intruder at the Party?, 3 AMSTERDAM L. F. 29 (2011); Jean-Paul Jacqué, The Accession of the European Union to the European Convention on Human Rights and Fundamental Freedoms, 48 CMLR 1005-06 (2011); Gragl, supra note 30, at 127; Pavlidis, supra note 83, at 65-66; Tobias Lock, End of an Epic? The Draft Agreement on the EU's Accession to the ECHR, 31 Y.E.L. 189 (2012).

121 Jacqué, supra note 121, at 1006.

122 This observation was already made by Martin Kuijer in regard to a possible EU reservation concerning the CFSP. Cf. Kuijer, supra note 121, at 29.
} 
one of the chief reasons of the accession, namely the protection of EU autonomy, will be endangered.

The restriction may concern either the mere jurisdiction of the ECtHR or the scope of international obligations of the EU imposed by the accession. The latter option seems more certain, because no state will be able to claim that despite the lack of the ECtHR's jurisdiction the EU breached an obligation. Therefore, the most appropriate method of carrying out this solution would be modification of the current Article 1(3) of the DAA which lays down the international obligations of the EU regarding the Convention. Its provision may be reworded by adding the following clause: "The accession does not impose on the EU any obligations pertaining to the Common Foreign and Security Policy."

Against such a formula, however, there are at least two counterarguments. First, the proposed clause seems to exceed the demands of the CJEU. It is plausible that the Court grants the ECtHR the jurisdiction over a narrow class of cases in the CFSP in which it has the jurisdiction. The language of the Opinion is not unequivocal in this part, yet it wouldn't be reasonable to exclude the ECtHR's jurisdiction over the CFSP if it weren't entirely necessary.

Nevertheless, this claim, which is of some value, needs to be assessed in the light of the second counterargument which points out that explicit restriction of the ECtHR's jurisdiction referencing the CFSP runs the recurring risk of the Strasbourg Court interpreting EU law. In this area, the risk is fairly low because the acts undertaken within the framework of the CFSP are relatively easy to recognize. If additional formulas are added-with the aim of modelling the ECtHR's jurisdiction after the one of the CJEU - the risk would be unacceptable. As far as the proposed wording is concerned, there seems to be no method of limiting the ECtHR's jurisdiction without referring to the CFSP, so the CJEU would have to accept this risk out of necessity.

Although these two classes of solutions seemingly exhaust the field of possibilities, it is possible to conceive of other methods of fulfilling the CJEU's demands. An option which could strike a balance between the two-without formal restricting either Courts' jurisdictions-consists of establishing a special procedure modeled after the prior involvement. The procedure would demand an amendment to the Treaties and a concordant clause in the AA. In cases in which the CJEU has no jurisdiction and the ECtHR is confronted with the task of assessing an act or omission of the EU in the light of its conformity with the Convention, the proceedings before the Strasbourg Court would be suspended. The AA would regulate this part as currently stated in the PIP. Then a small extension of the CJEU's jurisdiction as prescribed by the Treaties would be necessary, so that it would be entitled to adjudicate on the validity, or interpretation, of a provision of EU law. This extension would be of dynamic character, namely the CJEU wouldn't be granted the jurisdiction over the whole CFSP, but only over the cases pertaining to the CFSP on which the ECtHR has already started to adjudicate and stalled the proceedings. 
This solution, although complex from the technical point of view, might be the best compromise between the two aforementioned classes. First, it doesn't require limiting the ECtHR's jurisdiction, which is a great advantage in negotiations. Given that the non-EU Parties already accepted the PIP, the procedure in question wouldn't be too big of a concession. Secondly, this solution is undoubtedly easier to accept for the EU and its Member States than a major overhaul of the jurisdiction of the CJEU. Although the need to amend the Treaties poses an undeniable challenge, it would still be a rather technical modification and not a serious political reform for which the Member States have never displayed much eagerness.

Nonetheless, if the amendment of the Treaties isn't acceptable for EU negotiators-which is understandable in the light of the surge of anti-European movements ready to seize the opportunity in order to dismantle the integration-exclusion of the acts and omissions of the EU in the CFSP from the ECtHR's jurisdiction will be the only option.

\section{Conclusions}

The detailed analysis of all demands of the CJEU from Opinion 2/13 demonstrates that, contrary to initial worries among scholars, the requirements of the Court aren't impossible to meet. Eight out of ten demands are easy to realize. The other two-such as the points concerning the mutual trust in the area of Freedom, Security, and Justice and the jurisdiction over the Common Foreign and Security Policy-pose bigger problems. The real difficulty consists in satisfying the evident need for innovative legal thinking demanded by the requirements of the Opinion.

In this light, it doesn't seem necessary-let alone feasible-to resort to desperate measures, such as using primary law to circumvent the demands of the Court. ${ }^{123}$ Although the Opinion may be deemed disappointing in its tone and conclusions, its convoluted and often unclear argumentation might preserve a considerable amount of discretion both for the negotiators and for the CJEU itself, in the future. Given this specificity, the negotiators should follow a modest path. Fulfill the demands expressed in the most explicit manner and then, whenever the CJEU was not sufficiently specific, adopt solutions which don't extrapolate unnecessarily the severity of its requirements. The Court might modify its approach in the future, so it wouldn't be sensible to assume its high expectations if they aren't backed up by unambiguous conclusions of the Opinion. The tone of the Opinion, although hardly conducive to fruitful judicial dialogue with the ECtHR, shouldn't attract too much attention. The tone might change in the future. What the negotiators and scholars should concentrate

\footnotetext{
123 See Douglas-Scott, supra note 5; Leonard F. M. Besselink, Acceding to the ECHR notwithstanding the Court of Justice Opinion 2/13, VERFASSUNGSBLOG (Apr. 17, 2015), http://www.verfassungsblog.de/en/acceding-echrnotwithstanding-court-justice-opinion-213/\#.VJq5SFIM-U.
} 
upon are precise demands. Undoubtedly, legal ingenuity is needed to find appropriate solutions, but the task is not insurmountable. 
